\title{
GYŐRI ELIT ÉS A VÁROSFEJLŐDÉS - A GAZDASÁGI ÉS TÁRSADALMI FOLYAMATOK MEGÍTÉLÉSE ${ }^{1}$
}

\author{
(Local Elite and Urban Development - \\ the Outlook of Economic and Social Processes)
}

\section{CSIZMADIA ZOLTÁN - PÁTHY ÁDÁM}

Kulcsszavak:

helyi társadalmi elit vârosfejlödés lokális versenyképesség városkép

Egy nagyváros sikeressége nem csak az objektiv helyi gazdasági, társadalmi, kulturális adottságok és mechanizmusok jellegétöl, felhasználásától függ, hanem azoktól a szubjektivebb, akár kollektív jellegü véleményektól, képzetektől is, amelyek egyszerre lenyomatai, tükrözödései, de egyben meghatározói, motiváló elemei is az egyéni és közösségi társadalmi cselekvéseknek. Ezeket a véleményeket, képzeteket próbáljuk feltárni (kérdöives felméréssel) egy nagyvárosi térségben (Györ) és egy sajâtos helyzetü társadalmi csoport (helyi elit) esetében annak érdekében, hogy jobban megismerjük óket, mint a helyi társadalom meghatározó rétegét, illetve, hogy a város is jobban megismerje önmagat (gazdasági és társadalmi fejlödését és a jelenlegi adottságait) az általuk kifejtett vélemények tïkrében.

\section{Bevezetés}

A társadalmi elit kutatásának nagy hagyománya van a szociológiában (Mosca 1939; Mills 1972; Pareto 1972; Veblen 1992), sőt már magának az elitnek a fogalma is kérdéses, és állandó viták kereszttüzében áll (Takács 1998). Elsődlegesen a társadalmi struktúra, rétegződés, a hatalom és érdekérvényesítés oldaláról közelítve értékelődik fel ennek a társadalmi csoportnak a szerepe, illetve a hazai szakirodalomban az elit átalakulása, átváltozása, átrendezỏdése vagy éppen cirkulációja kapott eleinte (különösen a kilencvenes években) hangsúlyt. A városfejlődés, egy lokális gazdasági-társadalmi mezỏ dinamizálódása pedig komoly kutatási hagyományokkal rendelkezik a regionális tudományban (Enyedi 1988; Rechnitzer 2007; Szirmai 2009), és külỏnösen a fỏvárosok, nagyvárosok, regionális centrumok kedvelt célterületei az ilyen empirikus vizsgálatoknak (Izsák 2003; Szirmai et al. 2003), illetve egyre többen foglalkoznak a tervezés és a fejlódés összefüggéseivel is (Csanádi et al. 2010). Empirikus kutatásunk rendhagyó volta abból adódik, hogy igazából sem a helyi (gyỏri nagyvárosi térség) társadalmi elittel (mint csoportnak a szociodemográfiai attribútumaival), sem a helyi gazdasági-társadalmi fejlödés objektív tendenciáival nem foglalkozunk konkrétan, hanem arra teszünk kísérletet, hogy megmutassuk, mi jár a nagyvárosi térség meghatározó, prominens csoportjának a 
tagjai fejében saját városukról, annak fejlődéséről, szerepéről és jövőjéről. Az elit, mint kutatási objektum csak úgy nyilvánul meg, hogy milyen tükröt tart a város elé, és ez a tükrözỏdés mennyiben függ elit voltától. Az elit, mint szubjektum viszont több szerepet kap, hiszen a következő fejezetekben a lokális gazdasági-társadalmi folyamatok megítélésének számos lehetséges dimenziójában fejti ki a véleményét kirajzolva ez által egy egyedi (Győrs-specifikus) kollektív véleményt, domináns, véleményformáló közösségi alapmintát számos kérdésben. Az eredmények így már nem pusztán egy térség önismeretét, identitásképzését vagy annak erősítését segíthetik, hanem a helyi gazdaság és társadalom jövőbeli fejlesztési folyamatához is szolgáltathatnak prioritásokat, átfogó támpontokat vagy akár konkrét ötleteket.

A vizsgálatot a Széchenyi István Egyetemen futó nemzetközi kutatási projekt keretében végeztük 2008-ban, amely a vállalatok környezeti kapcsolataival foglalkozott (FP6 „New and Emerging Science and Technology” kutatási föirány „Corporate Culture and Regional Embeddedness" címú projekt). A projekt átfogó célja az volt, hogy feltárja, egy régió, egy város mit tehet annak érdekében, hogy az ottani gazdasági egységek működése még kedvezőbb legyen, illetve maga a gazdaság miként képes formálni az adott területi egység fejlödését, annak innovációs környezetét, humán erőforrásai fejlesztését, a környezet minöségét és fenntarthatóságát, valamint az életminőséget? Ennek keretében részkutatási célként, egy önkitöltős kérdöíves felmérés során a város meghatározó, befolyásos rétegében kérdeztünk rá arra, hogy mi a véleményük Győr helyzetéröl, a város és környéke jelenlegi fejlettségéről és pozíciójáról, annak gazdasági aspektusairól, milyen a város „személyisége” és szimbolikája, miként használják a társadalmi nyilvánosságot, melyek a társas aktivitás és közösségi élet jellemzöi ebben a csoportban? Mint látható, elsősorban az elit gondolkodásmódját és egy nagyvárosi térségről alkotott képzeteit, „kollektív reprezentációit” szerettuik volna feltérképezni, de emellett ennek a csoportnak, mint viszonylag homogén társadalmi rétegnek is megismertük bizonyos lényegi tulajdonságait.

\section{Módszertani kérdések}

A kérdőívezés postai úton kiküldött önkitöltős változatát alkalmaztuk. Már önmagában emiatt, de a kiválasztott célpopuláció sajátos társadalmi réteghelyzete miatt sem beszélhetünk reprezentativitási kritériumokról, hiszen nem ismerjük a város felső társadalmi rétegének pontos szerkezetét, összetételét. Így az eredmények nem általánosíthatók, nem Győr város lakosságának véleményét tükrözik. Kizárólag egy szủkebb, 'szakértőbb' csoportét, amelyben cégvezetők, politikusok, hivatalvezetök és értelmiségiek lettek beválogatva egy elözetes szürési folyamatot követöen. Összesen több mint 600 kérdőívet küldtünk ki a városban, egy előre meghatározott szủrési kritériumok alapján leválogatott célpopulációnak. Követve a hagyományos szociológiai elitelméletek legegyszerủbb felosztását gazdasági, politikai és kulturális/ értelmiségi elitcsoportokat különböztettünk meg, mégpedig elsődlegesen a foglalkozási 
pozíció alapján. Vezetö beosztású, döntéshozatali jogkörökkel rendelkezö vagy mértékadó, magas presztízsú személyekben gondolkodtunk. A kérdöíves felmérés alanyait már e három csoporton belüli egyéb, funkcionálisan jobban elkülönülő alcsoportok szerint, részletesebb osztályozást követve rendszereztük (1. táblázat).

\section{TÁBLÁZAT}

A megkérdezett helyi prominens személyek csoportositási rendszere (The Grouping System of the Local Elite)

\begin{tabular}{|c|c|c|}
\hline Politika, közigazgatás & Gazdaság, üzleti élet & $\begin{array}{c}\text { Társadalom, oktatás, } \\
\text { kultúra }\end{array}$ \\
\hline $\begin{array}{l}\text { - önkormányzati kép- } \\
\text { viselök } \\
\text { - országgyülési kép- } \\
\text { viselök } \\
\text { - megyei közgyülés } \\
\text { - önkormányzati veze- } \\
\text { tök } \\
\text { - hivatalok } \\
\text { - ügyészségek } \\
\text { - bíróságok }\end{array}$ & $\begin{array}{l}\text { - vállalkozások (TOP } \\
\text { 200) } \\
\text { - önkormányzati cégek } \\
\text { - kamarák } \\
\text { - szakmai érdekkép- } \\
\text { viseletek } \\
\text { - bankok }\end{array}$ & $\begin{array}{l}\text { - közoktatás } \\
\text { - felsőoktatási intéz- } \\
\text { mények } \\
\text { - kulturális intézmé- } \\
\text { nyek } \\
\text { - egészségügyi és szo- } \\
\text { ciális intézmények } \\
\text { - civil szervezetek } \\
\text { - ügyvédek, közjegy- } \\
\text { zők } \\
\text { - egyházi vezetök } \\
\text { - múvészek } \\
\text { - újságírók } \\
\text { - építészek }\end{array}$ \\
\hline
\end{tabular}

Forrás: Saját szerkesztés.

A több mint 600 megkeresett személy közül összesen 200-an töltötték ki a kérdőívet, így az általunk meghatározott sokaság egyharmadának ismerjük a véleményét bizonyos kérdések kapcsán. A kérdő́ivek feldolgozása és ellenőrzése során kiderült, hogy használható (nem túl hiányosan kitöltött) kérdőívböl összesen 171 van, így megközelítőleg a célcsoport 28\%-ának, tehát több mint egynegyedének elemezhetők a válaszai.

\section{A városi elit kérdöíves mintájának alapjellemzői}

A győri elit körében végzett felmérés személyes véleményeket, értékítéleteket és kollektív nézeteket, a közvélekedés jegyeit mérte fel. Ez indokolja, hogy részletesebben bemutassuk a 171 válaszadó társadalmi-demográfiai hátterét (2. táblázat). A válaszadók társadalmi háttere kellően összetett. A legnagyobb csoportot az „egyéb értelmiségi” gyủjtőkategória alkotja, amelybe ügyvédek, építészek, újságírók, egyházi vezetők tartoznak. Ez a csoport adja a minta egyharmadát. A második legnagyobb szegmens az üzleti élet és a helyi gazdaság vezetőiböl áll, a teljes minta egynegyedét adva. Ezt követi az oktatás, a kultúra és az egészségügyi, szociális 
szféra (nagyjából szintén 25\%-os összesített aránnyal), majd a képviselők, érdekképviseletek és az önkormányzat vezetöi következnek, jóval kisebb kitöltési és viszszaküldési aktivitással. Látható, hogy a politikai elit reprezentativitása kicsi, inkább az értelmiség és a gazdasági elit véleménye fog kirajzolódni a válaszok alapján.

Figyelembe véve a megkérdezettek társadalmi státuszát, nem meglepö, hogy a tipikus válaszadó 49 éves. A legfiatalabb 23, míg a legidősebb személy 75 éves a mintában. Korcsoportok szerinti bontásban a válaszadók egyharmada az ötvenes generációhoz tartozik, egynegyede pedig a negyvenes korosztályhoz. A negyven év alatti személyek aránya természetesen alacsonyabb (24\%), és a hatvan év felettiek csoportja is csak $16 \%$-os. A válaszolók és feltételezhetỏen a kiválasztott társadalmi réteg körében is az átlagosnál magasabb a házasok aránya a családi állapotot figyelembe véve. $80 \%$-uk házas, csak $10 \%$-uk nőtlen vagy hajadon, és alacsony az elváltak, élettárssal élők, illetve az özvegyek részaránya is.

\section{TÁBLÁZAT}

A minta legfontosabb jellemzöi (csak a domináns attribútumok vannak feltüntetve) (The Basic Properties of the Sample [Only the Dominant Attributes are Displayed])

\begin{tabular}{|c|c|c|c|}
\hline Jellemzö & Változó & $\begin{array}{l}\text { Gyakoriság }(N) \\
\text { vagy átlag }\end{array}$ & $\begin{array}{c}\text { Megoszlás } \\
(\%)\end{array}$ \\
\hline \multirow{3}{*}{$\begin{array}{l}\text { Legnagyobb } \\
\text { elitcsoport }\end{array}$} & Egyéb értelmiségi & 50 & $33 \%$ \\
\hline & Üzleti, vállalati & 37 & $24 \%$ \\
\hline & Oktatás, kultúra & 32 & $21 \%$ \\
\hline \multirow[t]{2}{*}{ Életkor } & Átlagéletkor (év) & 49 & \\
\hline & $\begin{array}{l}\text { Legnagyobb korcsoport } \\
\text { (51-60 év) }\end{array}$ & 56 & $33 \%$ \\
\hline $\begin{array}{l}\text { Családi álla- } \\
\text { pot }\end{array}$ & Házas & 135 & $80 \%$ \\
\hline \multirow{2}{*}{$\begin{array}{l}\text { Lokális iden- } \\
\text { titás }\end{array}$} & Jelenleg Györben él & 144 & $84 \%$ \\
\hline & $\begin{array}{l}\text { Közöttük: többgenerációs } \\
\text { györi }\end{array}$ & 75 & $53 \%$ \\
\hline \multirow[t]{4}{*}{ Városrész } & Belváros & 33 & $23 \%$ \\
\hline & Nádorváros & 30 & $21 \%$ \\
\hline & Révfalu & 22 & $16 \%$ \\
\hline & Szabadhegy & 14 & $10 \%$ \\
\hline \multirow{4}{*}{$\begin{array}{l}\text { Iskolai vég- } \\
\text { zettség }\end{array}$} & Legfeljebb gimnázium & 3 & $2 \%$ \\
\hline & Föiskola & 35 & $24 \%$ \\
\hline & Egyetem & 94 & $63 \%$ \\
\hline & $\mathrm{PhD}$ & 17 & $11 \%$ \\
\hline \multirow{3}{*}{$\begin{array}{l}\text { Családi háttér } \\
\text { szülök iskolai } \\
\text { végzettsége } \\
\text { alapján }\end{array}$} & $\begin{array}{l}\text { Egyik szuilő sem diplo- } \\
\text { más }\end{array}$ & 85 & $57 \%$ \\
\hline & Egyik szülő diplomás & 29 & $19 \%$ \\
\hline & Mindkét szülö diplomás & 35 & $24 \%$ \\
\hline
\end{tabular}

Forrás: Kérdöívek (2008). 
Györ és vonzáskörzete gazdasági és társadalmi életével, fejlődésével összefüggésben lényeges kérdés volt az egyének helyismerete, kötődése, lokális identitása. Ennek alakításában roppant fontos szerepet játszanak az alábbi tényezők. Hol élnek? Győrben vagy az agglomerációjában? Ha Győrben, akkor mióta élnek a városban? És melyik városrészben? A válaszadók 84\%-a jelenleg Győrben él. A 27 nem győri személy alapvetően a városhoz közel, az agglomerációs gyürủn belül lakik. Csak egy-két ember jár Komárom, Mosonmagyaróvár, Csorna vagy éppen Budapestnyi távolságról dolgozni a településre. A jelenleg Győrben lakók több mint fele itt is született, vagy a család akár több generációja is itt élt folyamatosan. További 44\%-uk „hosszú ideje” él a városban, és csak 3-4\% említette, hogy nemrég költözött a településre. Ezekböl az adatokból arra következethetünk, hogy a többségnek erős kötődése van a városhoz és térségéhez, és kellő ,,helyismerettel rendelkezik" a lokális társadalmi és gazdasági életet illetôen. Nem meglepő a térbeli elhelyezkedés, a lakóhely koncentrációjának mértéke. A leginkább preferált városrészek listaján az első helyen a Belváros szerepel, majd Nádorváros és Révfalu következik a sorban. Ebben a három városrészben él a győri interjúalanyok 60\%-a. A felső társadalmi rétegek, a magasabb státusú csoportok 2001. évi népszámlálás adatai alapján megfigyelhetô sajátos területi koncentrációját követi a jelen felmérés során kapott lakóhelyi térszerkezeti megoszlási struktúra is.

Az iskolai végzettség megfelel a társadalmi helyzetből, pozícióból fakadó követelményeknek. A 171 fő közül csak 3 személynek nincsen diplomája. A többségnek (63\%) egyetemi végzettsége van. A szocializáció és a későbbi véleményformálás egyik fontos társadalmi közege a család. A megkérdezett személyek családi státuszáról viszonylagos pontossággal a sziilők iskolai végzettsége alapján tájékozódhatunk a kérdőívben. Egy egyszerủ csoportosítással három családtípust alakítottunk ki: egyik szülő sem diplomás, csak az egyik szülő diplomás, mindkét szülö diplomás. Figyelembe véve a minta korszerkezetét, meglepően magas a diplomás szülőkkel rendelkezők aránya. A válaszadók 13\%-a nem adott választ, de a maradék 149 ember 43\%-ánál vagy az egyik, vagy akár mindkét szülő felsőfokú végzettséggel rendelkezik. A fiatalabb koresoportban pedig az arány meghaladja a 70\%-ot. Az idősebb korosztályban pedig a diploma után a gimnáziumi érettségivel rendelkező szülők dominálnak. A negyvenes és ötvenes korosztályra épülő adatbázisban minden negyedik személy olyan családban nött fel, ahol mindkét szüló diplomával rendelkezett.

\section{Györ fejlödésével kapcsolatos vélemények}

A város fejlettségét, illetve a múlt és a jövő fejlődési pályáinak értékelését két oldalról közelítettuik meg. Kíváncsiak voltunk egyrészt arra, hogy a helyi elit miként pozícionálja Györt a különféle adottságok, illetve a gazdasági fejlettség szempontjából. A másik megközelítés alapja a versenyképesség; a releváns kulcstényezők megítélésén keresztül próbáltunk képet kapni arról, hogy a válaszadók miként értékelik a város rendszerváltást követő fejlődését, illetve milyen feltételek teljesülését tekintik elengedhetetlennek ahhoz, hogy Győr közeljövőjét a dinamikus fejlödés és a több szempontú versenyképesség jellemezze. 
Csizmadia Zoltán - Páthy Ádám : Győri elit és a városfejlödés - a gazdasági és

társadalmi folyamatok megítélése. - Tér és Társadalom 24:(2) pp. 63-91. (2010)

\section{Hol is vagyunk valójában?}

Mielött a válaszok nyomán megkísérelnénk kijelölni Győr pozícióját a régióban, illetve a szélesebb közép-európai gazdasági és társadalmi térben, érdemes kiindulópontként megvizsgálnunk azt, hogy a helyi elit „önmagában” - konkrét vetélytársakkal való összehasonlítás nélkül - mennyire tartja ,európainak” a várost különbözó ismérvek és tényezơk alapján.

A válaszadókat arra kértïk, hogy szabadon említsenek meg öt olyan ismérvet, amelyek szuikségesek ahhoz, hogy egy várost fejlettnek, európainak tekinthessünk, és azt is mondják meg, hogy az általuk említett ismérvek jellemzőek-e Győrre, avagy sem. A válaszokból egyrészt következtethetünk arra, hogy milyenek az általános elképzelések egy fejlett városra vonatkozóan, de számunkra egyértelmüen fontosabb az a kérdés, hogy az egyes tényezők tekintetében milyen mértékben felel meg Györ az elvárásoknak. Tekintve, hogy nyitott kérdésről volt szó, a válaszok meglehetősen változatosak; a különféle tényezők kategorizálásával első lépésben 20, a későbbiekben 6 dimenziót alakítottunk ki. Ha csak az ismérvek említését nézzük, az látható, hogy a gazdasághoz, kultúrához és oktatáshoz kapcsolható tényezők fordulnak elö legnagyobb számban - az említett kategóriák egyenként a válaszok több mint 10\%-át teszik ki. Hasonlóan sokan említették az infrastruktúrával és a közlekedéssel kapcsolatos tényezóket; elmondható, hogy a válaszok nagyjából felét az említett öt kategória tartalmazza. Látható tehát, hogy a jellemvonások között a „,kemény” tényezők dominálnak, sokkal kisebb hangsúlyt kapnak azok az ismérvek, amelyek klasszikusan az élhetôség, életminöség jellemzöinek tekinthetők (szabadidő eltöltésének lehetôségei, sport, közösségi élet, szolgáltatások, arculat, környezetvédelem stb.).

A 3. táblázatban látható a válaszok megoszlása kategóriánként, emellett láthatjuk az egyes kategóriák meglétét jelző arányokat minden tényezőcsoport esetén.

Bár az eredmények azt mutatják, hogy az összes említés közül a meglévőnek, illetve hiányzónak tekintett ismérvek aránya nagyjából megegyezik, az egyes tényezők között jelentős különbségeket találhatunk. A táblázatban aláhúzva jelöltuik azokat a tényezőket, amelyeket a válaszadók több mint 60\%-a tekint Győrre jellemzönek, dőlttel pedig azokat, ahol ez az arány $40 \%$ alatt van. Látható, hogy a leggyakrabban említett három, széles gyủjtőkategóriának tekinthetö ismérvcsoport esetében magas a pozitív válaszok aránya, illetve a gazdasághoz szorosan kapcsolódó munkalehetőségek, valamint a földrajzi fekvés esetében találkozhatunk magas aránnyal. Sokkal több viszont az olyan tényezöcsoport, melyek esetében a válaszadók hiányosságokat látnak. A „leggyengébben” a közlekedés - ide tartozik az utak állapota, a forgalomszervezés, valamint a tömegközlekedés - teljesít; majdnem minden második válaszadó fontos tényezőnek tekinti, de csak kevesebb, mint egyötödük nyilatkozott úgy, hogy ebben a tekintetben Győr megfelelő adottságokkal rendelkezne. Hasonlóan alacsony az igenek aránya az idegenforgalom és a civil társadalmi aktivitás esetében, de itt maguknak az említéseknek a száma is jóval alacsonyabb, az elit nem tekinti tehát ezeket olyan meghatározó jellemzőnek, mint amilyen a közlekedés. 


\section{TÁBLÁZAT}

Egy fejlett európai város jellemzői

(The Envisioned Properties of a Well-developed European City)

\begin{tabular}{|c|c|c|c|c|}
\hline \multirow[b]{2}{*}{ Ismérv } & \multirow[b]{2}{*}{ Említés } & \multirow[b]{2}{*}{$\%$} & \multicolumn{2}{|c|}{ Györre jellemzö } \\
\hline & & & $\begin{array}{c}\text { Igen } \\
(\%)\end{array}$ & $\begin{array}{c}\mathrm{Nem} \\
(\%)\end{array}$ \\
\hline kultúra & 88 & 11,1 & $\underline{65,9}$ & 34,1 \\
\hline gazdaság & 86 & 10,8 & $\underline{84,9}$ & 15,1 \\
\hline oktatás & 84 & 10,5 & $\underline{83,3}$ & 16,7 \\
\hline közlekedés & 74 & 9,3 & 17,6 & 82,4 \\
\hline infrastruktúra & 71 & 8,9 & 47,9 & 52,1 \\
\hline rendezettség, tisztaság & 69 & 8,7 & 31,9 & 68,1 \\
\hline élhetőség, biztonság & 50 & 6,3 & 46,0 & 54,0 \\
\hline arculat, egyediség & 41 & 5,1 & 24,4 & 75,6 \\
\hline környezetvédelem & 33 & 4,1 & 45,5 & 54,4 \\
\hline méret, központi funkciók & 31 & 3,9 & 22,6 & 77,4 \\
\hline $\begin{array}{l}\text { városvezetés, stratégiai } \\
\text { tervezés }\end{array}$ & 28 & 3,5 & 28,6 & 71,4 \\
\hline idegenforgalom & 27 & 3,4 & 18,5 & 81,5 \\
\hline szolgáltatások & 25 & 3,1 & 36,0 & 64,0 \\
\hline munkalehetőség & 19 & 2,4 & $\underline{63,2}$ & 36,8 \\
\hline kutatás, innováció & 18 & 2,3 & 38,9 & 61,1 \\
\hline közösségi élet, civilek & 15 & 1,9 & 20,0 & 80,0 \\
\hline földrajzi helyzet & 11 & 1,4 & $\underline{81,8}$ & 18,2 \\
\hline $\begin{array}{l}\text { értékmegörzés, örökség- } \\
\text { védelem }\end{array}$ & 10 & 1,3 & 20,0 & 80,0 \\
\hline szabadidő & 9 & 1,1 & 33,3 & 66,7 \\
\hline életminőség & 7 & 0,9 & 57,1 & 42,9 \\
\hline összesen & 796 & 100,0 & 48,6 & 51,4 \\
\hline
\end{tabular}

Forrás: Kérdőívek (2008).

Összességében azt láthatjuk, hogy Győr, mint európai város képe erősen féloldalas a helyi elit szemében. A válaszadóknál szinte közmegegyezés-szerủen elöforduló alaptényezők tekintetében egyértelmüen pozitívnak tekinthetö az értékelés, viszont az élhetöséget, komfortérzetet, valamint az önálló arculatot, egyediséget biztosító jellemzők megléte már sok esetben kérdéses. Tekintve azt, hogy az utóbbiakban említett „,másodlagos” tényezők alakításában magának az elitnek is komoly szerepe lehet, az értékelés valamilyen szempontból akár egyfajta önkritikának is felfogható lenne. Az önálló arculattal, egyediséggel, kreativitással kapcsolatos problémák a későbbiekben is visszaköszönnek, amikor a város szimbólumaival foglalkozunk.

A város pozicionálásánál kísérletet tettünk annak feltérképezésére, hogy miként látja a helyi elit Győr helyzetét Magyarországon belül, illetve Közép-Európában. Arra kértuik a válaszadókat, hogy a hasonló méretkategóriába tartozó közép-európai váro-sok közül jelöljenek meg fejlettebbeket, azonos fejlettségüeket, valamint fejletlenebbeket, 
mint Györ; valamint határozzák meg és jellemezzék a város jelenlegi és lehetséges jövőbeli versenytársait, egyúttal azt is megjelenítve, hogy mi a rivalizálás alapja.

A Györnél fejlettebb városok esetében nem meglepő, hogy a túlnyomó többséget az osztrák és német városok képviselik. Graz abszolút listavezetö, a válaszadók több mint fele ( 87 fö) említette (4. táblázat), ez az összes említés 21,3\%-át teszi ki, tekintve, hogy egy válaszadó három várost jelölhetett meg minden kategóriában. A második és harmadik helyen Linz és Salzburg szerepel, Bécs is kapott 25 említést, és ha hozzászámoljuk a többi megemlített osztrák várost (St. Pölten, Klagenfurt), akkor elmondható, hogy a jelölések csaknem fele $(49,0 \%)$ tartozik Ausztriához. Sok német város szerepel a listán, közülük is kiemelkedik München, Regensburg és Drezda. A volt szocialista országok közül Csehország emelkedik ki; Prága és Brno sok jelöléssel rendelkezik, rajtuk kívül még Pozsonyt és Maribort említhetjük, mint gyakran szóba jövő vonatkoztatási pontokat. A 408 jelölés közül mindössze 6 esett magyar városra (Debrecen, Szeged, Pécs).

A Györrel azonos fejlettségü városok esetében már jelentősebb a szórás; a legnagyobb arányt cseh, lengyel és szlovák városok képviselik (4. táblázat). A fejlettebbeknél domináló osztrák és német városok csak szórványosan jelennek meg ebben a kategóriában, itt is elsôsorban a volt NDK nagyvárosai (Drezda, Lipcse, Chemnitz, Halle, Erfurt) kerültek jelölésre.

A Györnél fejletlenebb városok listáján a szlovák és román városok dominálnak (4. táblázat), a jelölések nagy részét ezek teszik ki. Különösen érdekes Kassa és Nyitra helyzete, e két város mind az azonosak, mind a fejletlenek között a legtöbbször említettek közé tartozik.

\section{TÁBLÁZAT}

A tiz leggyakrabban emlitett város kategóriánként

(The 10 Most Frequently Mentioned Town/City in 3 Categories)

\begin{tabular}{|c|c|c|c|c|c|}
\hline \multicolumn{2}{|c|}{ Fejlettebb, mint Györ } & \multicolumn{2}{|c|}{ Györrel azonos } & \multicolumn{2}{|c|}{ Györnél fejletlenebb } \\
\hline Város & Emlités & Város & Említés & Város & Emlittés \\
\hline Graz & 87 & Brno & 50 & Arad & 49 \\
\hline $\operatorname{Linz}$ & 43 & Krakkó & 38 & Nyitra & 35 \\
\hline Salzburg & 39 & Kassa & 35 & Temesvár & 29 \\
\hline Prága & 29 & Pozsony & 29 & Kassa & 26 \\
\hline Bécs & 25 & Nyitra & 23 & Nagyvárad & 23 \\
\hline Brno & 20 & Plzen & 22 & Kolozsvár & 22 \\
\hline München & 19 & Wroclaw & 10 & Eszék & 12 \\
\hline Pozsony & 19 & Maribor & 10 & Eperjes & 10 \\
\hline Regensburg & 15 & Graz & 9 & Maribor & 10 \\
\hline Drezda & 14 & Lipcse & 9 & Szabadka & 8 \\
\hline
\end{tabular}

Forrás: Kérdöívek (2008).

A válaszadókat arra is megkértük, hogy jelöljék meg a Györnél fejlettebb városokat csak Magyarországra koncentrálva. Budapest (101 említés) mellett Debrecen (103) 
emelkedett ki a mezőnyböl, a két várost a válaszadók csaknem kétharmada fejlettebbnek tartja Győrnél. A válaszadók több mint egynegyede említette Pécset, Szegedet és Székesfehérvárt, a többi város (Miskolc, Szombathely, Sopron, Veszprém, Nyíregyháza, Kecskemét, Budaörs, Esztergom) csak elvétve került elö.

Győr jelenlegi versenytársainak megjelölésénél kétfajta alapvető motivációt lehet felfedezni. Az egyik csoportba tartoznak azok a magyar nagyvárosok, amelyek földrajzi elhelyezkedésüiket tekintve nem igazán lehetnek regionális vetélytársak, de hasonló méretük és funkcióik konkurens pozícióba helyezik őket (Debrecen, Szeged, Pécs). A másik kategóriát a regionális versenytársak képviselik; itt már hangsúlyozottan megjelennek az országhatáron kívüli - elsősorban szlovákiai - települések. A versenytársakat annak alapján is tipizáltuk, hogy milyen tekintetben jelentenek konkurenciát Gyôr számára. Látható, hogy a legfontosabb versenytársak között vannak olyanok, amelyeket a válaszadók méretük és funkcióik tekintetében abszolút dominánsnak tekintenek Györhöz képest (Bécs, Budapest és bizonyos tekintetben Pozsony). Vannak klasszikus regionális vetélytársak (Sopron, Szombathely), valamint találhatunk olyan városokat, amelyek sokkal inkább csak egy speciális területen jelentenek konkurenciát Győr számára (Nyitra, Székesfehérvár). Az említések nagy többségében gazdasági szompontokat jelöltek meg a válaszadók a rivalizálás alapjaként; speciális példa lehet Pécs, amely elsősorban kulturális szempontból konkurens - minden valószínüség szerint az Európa Kulturális Fövárosa cím elnyerése számít döntő faktornak -, illetve Szombathely, mint közigazgatási rivális - vélhetően a régióközpont kijelölésével kapcsolatos kérdések miatt. Az 5. táblázatban látható Györ tíz legjelentősebb jelenlegi vetélytársa ezen kritériumok alapján osztályozva.

\section{TÁBLÁZAT}

Györ jelenlegi vetélytársai

(The Actual Competitors of Györ)

\begin{tabular}{lcccc}
\hline \multicolumn{1}{c}{ Város } & Említés & Gazdasági & Kulturális & Közigazgatási \\
\hline Pozsony & 74 & +++ & & + \\
Székesfehérvár & 54 & +++ & & \\
Szombathely & 43 & + & + & +++ \\
Pécs & 26 & + & +++ & \\
Bécs & 23 & +++ & +++ & \\
Sopron & 18 & ++ & + & + \\
Debrecen & 17 & ++ & & \\
Graz & 12 & +++ & & \\
Budapest & 12 & +++ & ++ & + \\
Nyitra & 9 & ++ & & \\
\hline
\end{tabular}

Jelmagyarázat: +++ erösen jellemző, ++ jellemzö, + elvétve említett, nincs jelölés - egyáltalán nem jellemzö.

Forrás: Kérdöívek (2008). 
Ha arra a kérdésre keressük a választ, hogy kik lehetnek Györ versenytársai a jövöben, jelentős elmozdulásokat láthatunk. Bár ennél a kérdésnél jóval alacsonyabb volt az érvényes válaszok száma, mint az elözőnél, ettől függetlenül jól megragadható a versenytársak összetételének megváltozása. Pozsony elveszti vezetö pozícióját a vetélytársak között, viszont ezzel párhuzamosan jelentősen felértékelödnek az egyéb szlovákiai városok (Nyitra, Kassa, Dunaszerdahely). Ha csak a hazai versenytársakat tekintjük, akkor az látható, hogy a régión belüli, illetve közeli városok szerepe erösödik jelentős módon.

Szembetủnö, hogy a szlovákiai városok belépése a vetélytársak közé a gazdasági versengést erösíti; Nyitra és Kassa is egydimenziós konkurenciaként jelentkezik, de érvényes ugyanez a kevesebb említést kapott szlovákiai városokra (Érsekújvár, Dunaszerdahely, Eperjes) is. Látható, hogy Szombathely és Sopron válnak a jövöben a leginkább jelentös versenytársakká a györi elit véleménye szerint. Szombathely esetében leginkább a közigazgatási funkciók és a városvezetések közötti különbség áll a középpontban, míg Sopron elsősorban kulturális tekintetben potenciális versenytárs, de többen érzik úgy a válaszadók közül, hogy a város egyedi arculatának kialakítása és az ehhez kapcsolható pozitív hatások - idegenforgalom, rendezvények - tekintetében Győr elött fog járni a közeljövőben. Megfigyelhetö, hogy Sopron és Szombathely jövőbeli vetélytársként való említése kéz a kézben jár egymással, 14 olyan válaszadó volt, aki mindkét várost megemlítette, ez a legmagasabb arányt kitevö város-pár, a valamelyik települést említők 40\%-ánál találhatunk közös említést.

\section{TÁBLÁZAT}

Györ lehetséges jövőbeli vetélytársai

(Possible Competitors of Györ in the Future)

\begin{tabular}{lcccc}
\hline \multicolumn{1}{c}{ Város } & Említés & Gazdasági & Kulturális & Közigazgatási \\
\hline Szombathely & 26 & ++ & + & +++ \\
Sopron & 25 & & +++ & + \\
Nyitra & 22 & +++ & & \\
Székesfehérvár & 14 & +++ & & \\
Pozsony & 13 & +++ & & \\
Kassa & 11 & +++ & & \\
Pécs & 10 & & +++ & \\
Veszprém & 10 & + & ++ & \\
Szeged & 9 & + & ++ & \\
Bécs & 6 & ++ & + & \\
\hline
\end{tabular}

Jelmagyarázat: +++ erősen jellemzó, ++ jellemzó, + elvétve említett, nincs jelölés - egyáltalán nem jellemzö

Forrás: Kérdőívek (2008).

A versenytársakkal kapcsolatban rákérdeztünk arra is, hogy milyennek látják a Győrhöz képest való fejlettségüket abban a vonatkozásban, amiben konkurensnek tekintették öket. A jelenlegi versenytársak alapvetően aszerint bonthatók kategóriákra, 
hogy melyik országban találhatók. Egyértelmüen elönyben lévönek tekintik Györnél a válaszadók az osztrák városokat, emellett pedig még azokat a megemlített konkurenseket, amelyek mérete és gazdasági potenciálja nehezen hasonlítható össze városunkkal (Budapest, Prága). A Györnél némileg jobb helyzetben lévő versenytársak közé került Brno, Pozsony és Sopron, azonos helyzetben van a magyarországi versenytársak többsége, a szlovákiai városokkal szemben jelenleg Györ van némi előnyben. A jövőbeli versenytársakkal való összehasonlítás esetében azt láthatjuk, hogy a megerősödő konkurensek többsége (Szombathely, Nyitra, Kassa) jelenleg még versenyhátrányban van Györrel szemben, de a válaszadók a szlovák városoknál föként a dinamikus gazdasági fejlődést említették a jövőbeli versenyhelyzet alapjaként, általában úgy, hogy a pozíciók a jövőben Győr hátrányára fognak megváltozni.

\section{Győr versenyképessége, a versenypoziciók alakulása}

A város versenyképességének vizsgálatánál nemcsak arra voltunk kíváncsiak, hogy miként alakultak Győr versenypozíciói a közelmúltban, illetve miként fognak a jövőben, hanem arra is, hogy melyek azok a kulcstényezök, amelyek kiemelt fontosságúak a versenyképesség szempontjából.

Elsőként azt a fejlődési pályát vizsgáljuk, amelyet Győr a rendszerváltás óta bejárt. Arra kértük a válaszadókat, hogy négy időpontra (1990, 1995, 2000, 2007) vonatkozóan értékeljék Győr versenyképességének alakulását, valamint próbálják ugyanezt meghatározni a közeljövőre vonatkozóan is. Ha a múltra vonatkozó görbét tekintjük, akkor azt láthatjuk, hogy a györi elit általános véleménye szerint a város versenyképessége a rendszerváltáskor a nulláról indulva jelentős erösödésen ment keresztül 2000-ig, de az azt követő időszakban némileg visszaesett. Nem tekinthető azonban általánosnak ez a vélekedés, ha a mintát megbontjuk az alapján, hogy a válaszadók milyen hivatáscsoportba tartoznak (1.ábra).

A versenyképesség alakulásának megitélésében alapvetỏen két nagy csoport különíthető el annak alapján, hogy melyik elitcsoportba tartozik a válaszadó. A kilencböl öt csoport esetében nagy vonalakban az általános vélekedés érvényesül, viszont a mủvészek, az önkormányzathoz köthetỏ válaszadók, valamint az egyéb intézmények vezetỏi és alkalmazottai több szempontból is eltérnek az átlagtól. Míg a többi csoport esetében a versenyképesség 2000-re vonatkozó értékelése nagyon magas (a -3-tól +3-ig terjedő skálán általában 2 körüli), addig a „,kilógó” kategóriák esetében ezek az értékelések szignifikánsan alacsonyabbak. De ami még jelentösebb különbség: a három említett elitcsoport esetében teljesen eltér az átlagtól a 2000-2007 közötti időszak megítélése, ugyanis itt pozitív tendenciákat találhatunk erre az időszakra is, tehát szerintük Györ versenyképessége ebben az idöszakban is növekedett. Eltủnik viszont ez a különbség akkor, ha a jövőre vonatkozó várakozásokat nézzük. Az összes válaszadó mintegy fele $(46,2 \%)$ nyilatkozott úgy, hogy Györ versenypozíciója javulni fog a jövőben, azok aránya, akik szerint romlik, mindössze $18,5 \%$. Csoportokra bontva azt láthatjuk, hogy a város jelenlegi versenyképességének 
Csizmadia Zoltán - Páthy Ádám : Győri elit és a városfejlödés - a gazdasági és

társadalmi folyamatok megítélése. - Tér és Társadalom 24:(2) pp. 63-91. (2010)

megítélésében az átlagtól eltérő három csoport semmivel sem tekinthetỏ optimistábbnak a többinél, söt, az önkormányzatnál dolgozók között a legkisebb azoknak az aránya, akik a versenyképesség javulását várják a közeljövöben.

\section{1. ÁBRA}

A versenyképesség alakulásának megítélése hivatáscsoport szerint (The Evolution of the Town's Development According to the Opinion of Different Elite-groups)

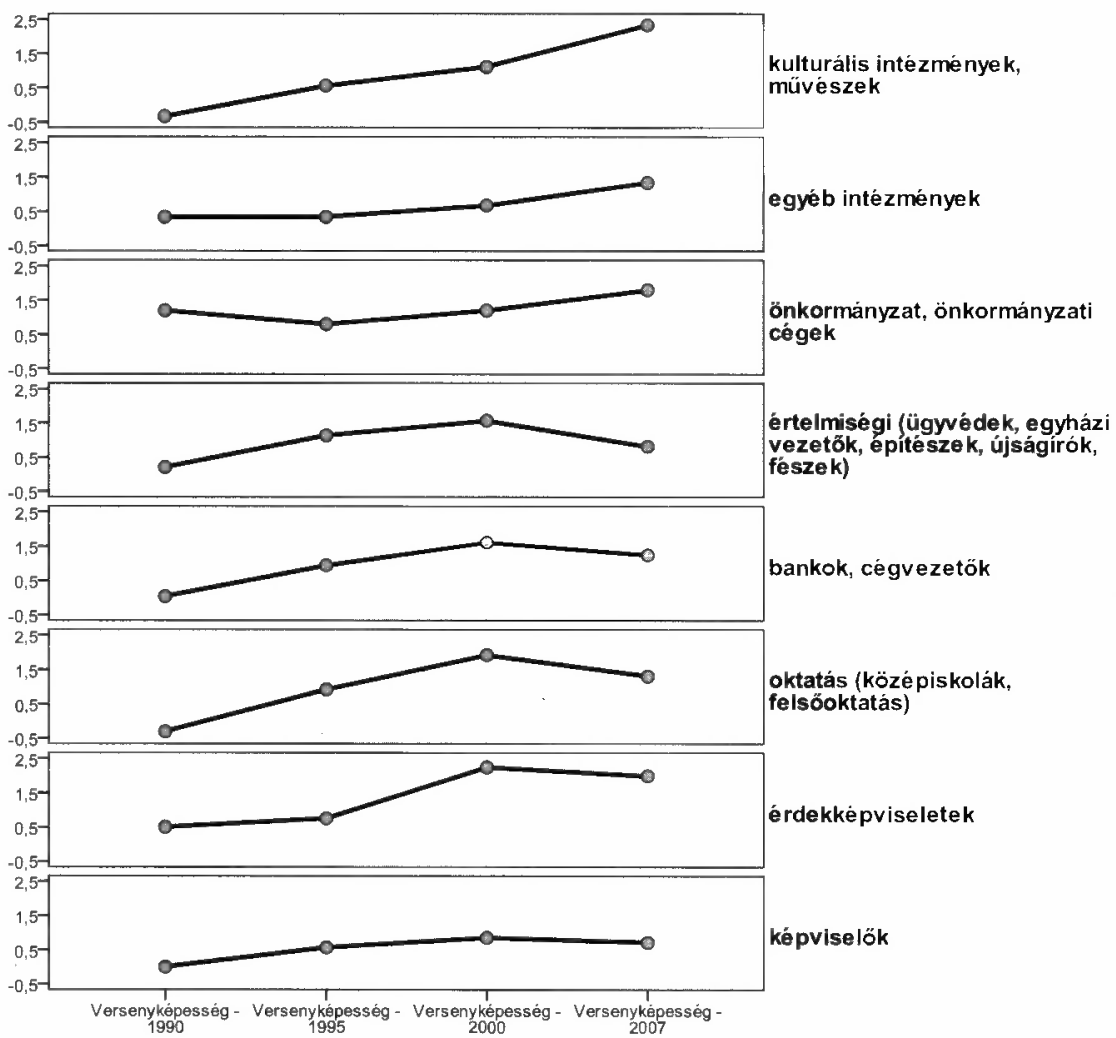

Forrás: Kérdőívek (2008).

Visszatérve a versenyképesség közelmúltbeli változásainak értékeléséhez, bizonyos szocio-demográfiai mutatók tekintetében is találhatunk jelentős különbségeket. Az életkor és az iskolai végzettség jelentősen befolyásolja Györ versenyképességének megítélését. Az idősebbek esetében a korábban már leírt különbséggel találkozunk; a 60 év felettiek pozitív elmozdulást észleltek a versenyképesség tekintetében 2000 és 2007 között, míg a többi korcsoport véleménye ellentétes. A különböző iskolai végzettség alapján képzett csoportok vizsgálatakor megfigyelhetö, hogy a magasabb végzettségủek konzisztensebben, egyenletesebb folyamatként látják Győr versenyképességének változását. 
Csizmadia Zoltán - Páthy Ádám : Győri elit és a városfejlödés - a gazdasági és társadalmi folyamatok megítélése. - Tér és Társadalom 24:(2) pp. 63-91. (2010)

A versenyképességet biztosító tényezők fontosságának megítéléséhez négyfokú skálákat alkalmaztunk. A különbözö tényezöket négy csoportba soroltuk:

- Gazdaság

- Oktatás, kultúra, egészségügy

- Helyi kormányzás

- Életkörülmények

Az átlagpontszámok alapján elmondható, hogy mind a négy dimenzió képviselteti magát a legfontosabbnak tartott tényezők között. A legmagasabb átlagpontszámmal a felsóoktatási intézmények fejlesztése szerepel, de a válaszadók túlnyomó többsége a közbiztonságot, illetve a helyi kis- és középvállalkozások fejlesztését is a kiemelten fontos tényezők közé sorolta.

\section{2. ÁBRA}

A versenyképességet biztositó tényezök átlagos értékelése

(The Evaluation [Mean Score] of the Factors of Local Competitiveness)

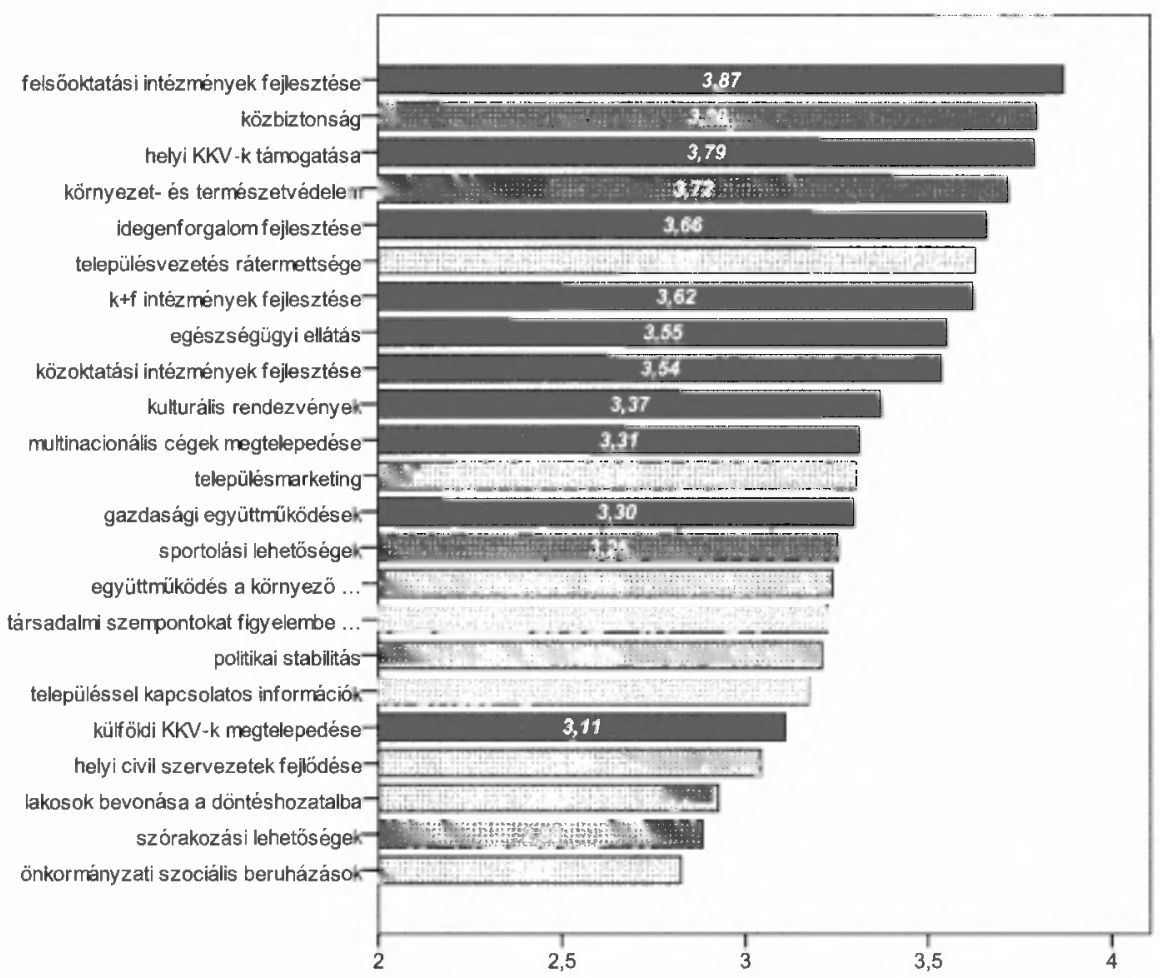

Jelmagyarázat: legsötétebb szürke - oktatás, kultúra, egészségügy, sőtétszürke - gazdaság, középszürke - êletkörülmények, halványszürke - helyi kormányzás

Forrás: Kérdöívek (2008). 
A 2. ábra alapján elmondható, hogy a helyi kormányzással kapcsolatos feltételek "lógnak ki" némileg a többi közül; csak a településvezetés rátermettsége ért el 3,5 feletti átlagot, a többi ide tartozó jellemzőt kevésbé tartják fontosnak a válaszadók. Ha az értékelések struktúráját összevetjük azzal, hogy a győri elit miként vélekedett egy fejlett európai város feltételrendszeréröl, akkor sok hasonlóságot tapasztalhatunk. Az ott viszonylag ritkán említésre kerülő „puha” tényezők (civil társadalom, szabadidő) itt sem kaptak magas értékelést. Mindenképpen említésre méltó még a gazdasági tényezők közötti kontraszt; a helyi vállalkozások fejlesztését sokkal fontosabbnak tekintik a megkérdezettek, mint újabb multinacionális cégek vagy külföldi tulajdonú kisebb vállalkozások Győrben való letelepedését.

A négyfokozatú értékeléssel párhuzamosan arra is megkértük a válaszadókat, hogy jelöljék meg a tényezök közül a három legfontosabbat. Ebben az esetben érdekes módon megváltozik a sorrend, a helyi kis- és középvállalkozások fejlesztése kerül az élre 72 említéssel; a többi fontosnak tartott tényezö sokkal kevesebb egyenként mintegy 30 - jelölést kapott. Érdekesség, hogy itt megjelenik a multinacionális cégek megtelepedése, tehát elmondható, hogy azok nagy része, akik kiemelten fontosnak tartják ezt a területet, a három leginkább fontos tényező közé is beválogatják. Fordított viszont a helyzet a felsőoktatás fejlesztésének megítélésében; a válaszadók túlnyomó többsége szerint kiemelt fontossággal bír, de viszonylag kevesen helyezik az első számú prioritások közé.

\section{A helyi gazdaság jellemzöi}

A gazdasági jellemzókről szóló fejezetben kísérletet teszünk arra, hogy az ágazati struktúráról alkotott vélemények alapján feltérképezzük Györ gazdaságának stabil, illetve átalakuló elemeit, valamint feltárjuk azokat a sajátosságokat, amelyek megkuilönböztetik a várost az ország többi részétől, illetve Nyugat-Európától a munkakultúra és a munkaszervezés területén. Ezen kívül kitérünk az innovativitásra, mint a dinamikus gazdasági fejlődés kulcstényezőjére, áttekintve a feltételeket és az intézményrendszert.

\section{Ipari hagyományok, húzóágazatok}

A győri gazdaság szerkezetének feltérképezésére egy olyan kérdést használtunk, amely egyaránt rákérdez az ágazatok múltbeli hagyományaira, jelenlegi súlyára, valamint jövőbeli fontosságukra. A hagyományok és a jövőbeli fontosság összehasonlitásával szemléletes képet kapunk arról, hogy milyen irányúak Győr gazdaságszerkezetének átalakulási folyamatai, illetve milyennek kellene lenniük. 
Az ágazatokat a hagyományok és a jövőbeli fontosság tekintetében négy kategóriába sorolhatjuk.

1) Vannak olyan, Győrben nagy hagyományokkal rendelkező ágazatok, amelyeknek egy modern termelési struktúrában elhanyagolható a jelentőségük. Ide tartozik elsősorban a textilipar, a mezögazdaság és valamilyen mértékben az élelmiszeripar. A megkérdezettek a meglévő hagyományokhoz képest a jövőben szignifikánsan kisebb fontossággal bírónak tekintik az építóipart és a müanyagipart is.

2) A második kategóriába azok az ágazatok tartoznak, amelyek jelentős hagyományokkal rendelkeznek a városban, és a jövőben is fontos pozíciót kell elfoglalniuk a gazdasági struktúrában. Ilyen az autóipar, a logisztika, a turizmus és ide tartoznak a pénzügyi szolgáltatások is.

3) Olyan, többnyire tradicionálisnak tekinthető iparágak, amelyek hagyományai nem túl jelentősek Győrben, de a jövőben fontosak lehetnek. Ilyen az elektronika, a múszeripar, a mechatronika és az energetika, és a helyi elit szerint ide sorolandó még az infotechnológia és a környezeti technológiák is.

4) A jövő gazdaságának néhány meghatározó ágazata, amelyek szinte egyáltalán nem rendelkeznek hagyományokkal a városban, de a jövőben bizonyos fontosságra tehetnek szert. Ide tartozik a géntechnológia, a biotechnológia és a nanotechnológia.

A 3. ábrán látható számértékek azt jelölik, hogy a megkérdezettek hány százaléka tartotta hagyományokkal rendelkezőnek, illetve a jövőben fontosnak az adott ágazatot.

Ugyanezen ágazatok jelenlegi szerepét Győrben egy ötfokú skálán vizsgáltuk.

A kapott eredményeket nem tudjuk egyértelmủen elhelyezni a hagyományok és a jövőbeli fontosság közé, több olyan ágazat van, amely a fentiekben vizsgált értékelésektöl eltéróen viselkedik. Természetesen némileg más jellegủ ez a kérdés, ugyanis itt nem igen-nem válaszokra voltunk kíváncsiak, hanem egy több elemủ skálán próbáltuk meg mérni az adott ágazat fontosságát (4. ábra).

Látható, hogy nagyon erös dominanciával rendelkezik az autóipar, az átlagpontszámok alapján a többi számotevő súlyúnak tartott iparág is jelentősen le van maradva hozzá képest. Az is kiderül az értékelésekből, hogy a nagy hagyományokkal rendelkezö, de a jövőben jelentőségükből vesztő ágazatokat (textilipar, élelmiszeripar, mezőgazdaság) már a jelen helyzetre vonatkozóan sem tartják jelentős súlyúnak a megkérdezettek. Meglepő viszont, hogy az autóipar mögött a turizmus kapta a második legmagasabb pontszámot az ágazatok közül, miközben a város adottságaival és jellemzőivel kapcsolatos vélemények között többször is visszaköszönnek magának az idegenforgalomnak, illetve az ezt kiegészítő, élénkítő feltételeknek a hiányosságai. Látható, hogy azok közül az iparágak közül, amelyek nem tekinthetôk a városban jelentős tradíciókkal rendelkezőknek, de a jövő szempontjából fontosak, több már jelenleg is megfelelő súllyal van jelen a gazdasági szerkezetben (elektronika, infotechnológia, környezeti technológiák). Ebből kiindulva 
Csizmadia Zoltán - Páthy Ádám : Győri elit és a városfejlödés - a gazdasági és

társadalmi folyamatok megítélése. - Tér és Társadalom 24:(2) pp. 63-91. (2010)

elmondhatjuk, hogy a győri elit véleménye szerint a gazdasági szerkezet sok elemében megfelelö alapokkal rendelkezik ahhoz, hogy dinamikus fejlödést és versenyképességet biztositó struktúrává váljon a jövöben.

\section{3. ÁBRA}

A különböző ágazatok hagyományai és jövőbeli fontosságuk Györben (The Traditions and Future Importance of Economic Sectors)
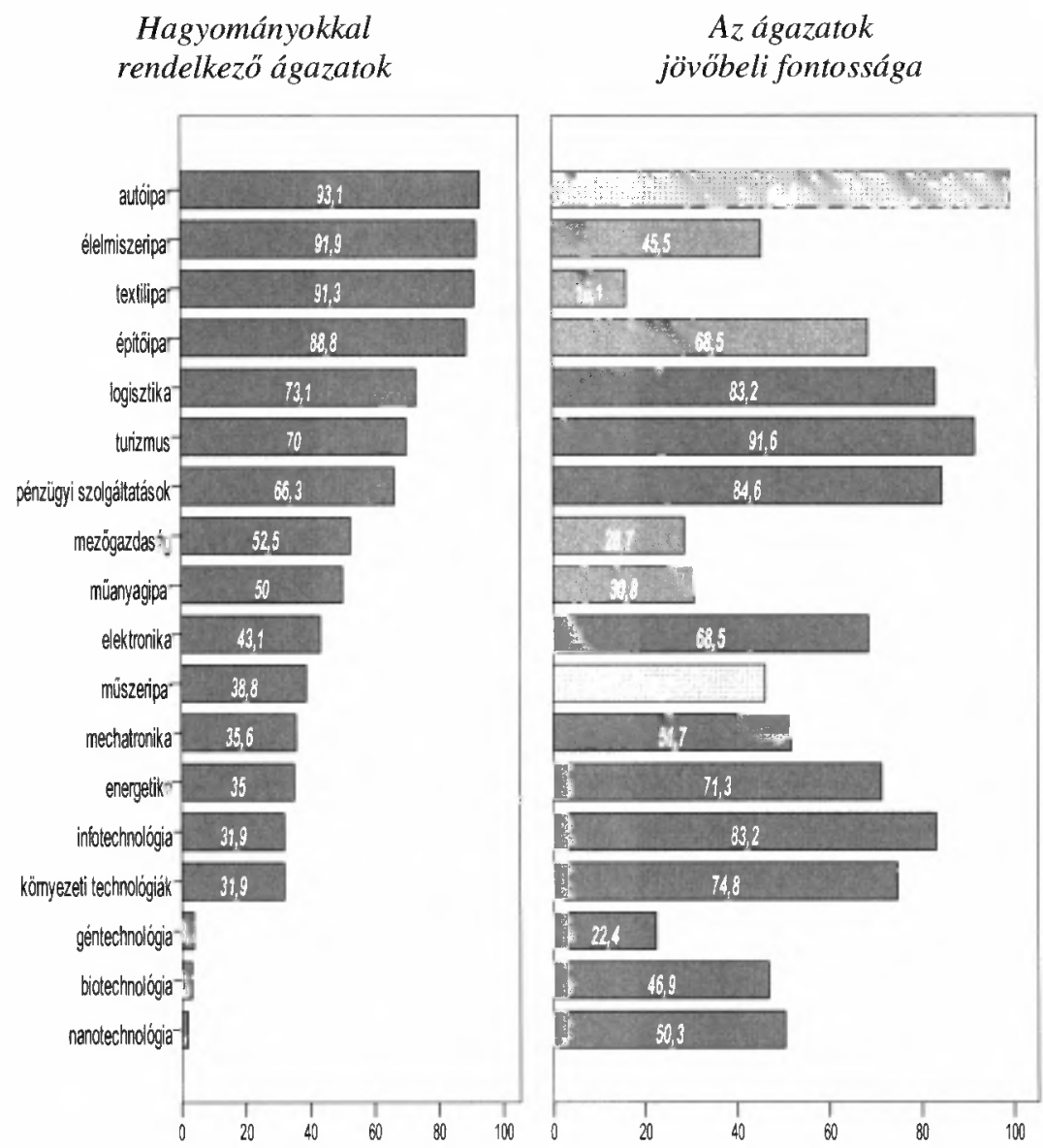

Jelmagyarázat (a jobb oldali táblán): sötétszürke - jelentóségüket növelö ágazatok (több mint $10 \%$ növekedés), halványszürke - stagnáló ágazatok (10\%-nál kisebb változás), középszürke jelentôségüket elvesztő ágazatok (több mint 10\% csökkenés)

Forrás: Kérdóívek (2008). 


\section{4. ÁBRA}

A különböző ágazatok fontossága Györ jelenlegi gazdasági szerkezetében (The Importance of Some Sectors in the Actual Economic Structure of Györ)

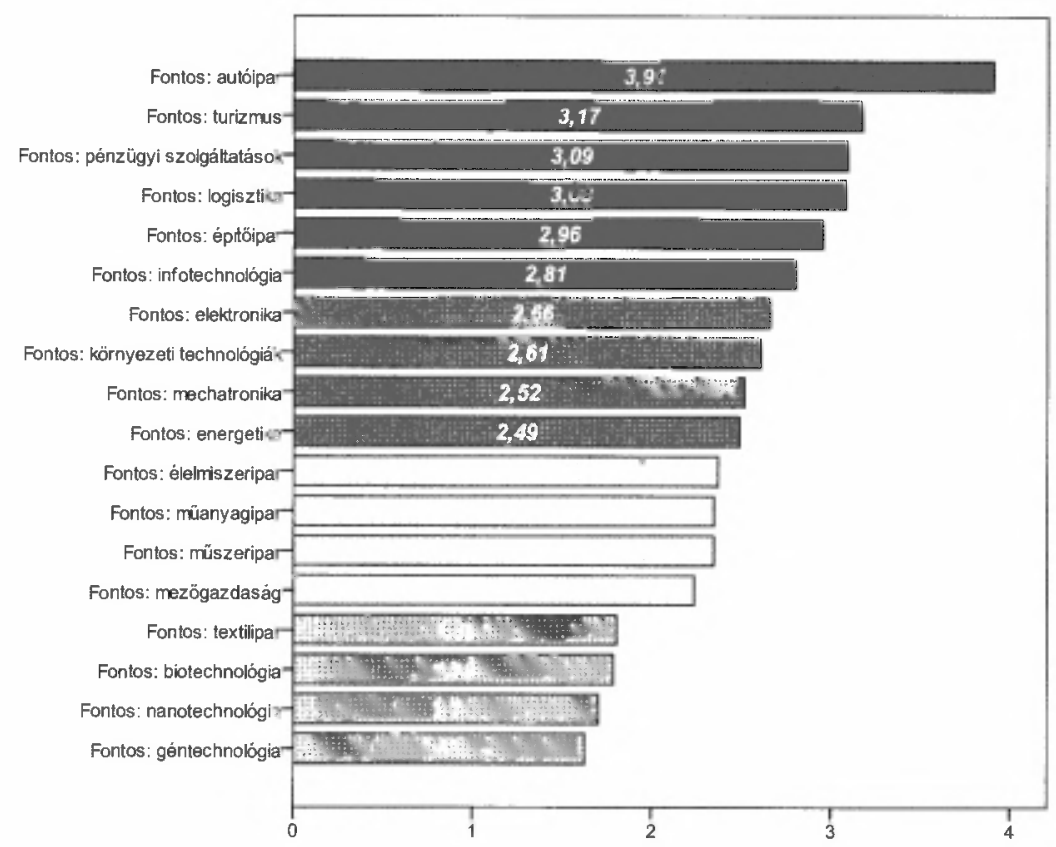

Forrás: Kérdőívek (2008).

\section{$A z$ innováció feltétel- és intézményrendszere}

Arra a kérdésre, hogy általában innovatívnak tekinthetö-e a város, a megkérdezettek $65,5 \%$-a felelt igennel. Ahhoz, hogy árnyaltabb képet kapjunk, áttekintettük azokat az alapvetö feltételeket, amelyeknek a megléte elengedhetetlenül fontos az. innovációhoz. A négy alapfeltétel a kutatás-fejlesztési infrastruktúra, a humán háttér, a pénzügyi erőforrások rendelkezésre állása és a vállalkozások hozzáállása volt, melyek meglétét négyfokozatú skálán mértuik.

A részletesebb bontás nagyjából alátámasztja a kedvezőnek mondható vélekedést az innovációról, a különböző feltételek is inkább pozitív értékelést kaptak. Közülük is kiemelkedik a humán háttér, azaz a szakemberek és a megfelelő szaktudás megléte; ez a kritérium átlagosan 2,98 pontot ért el a négyfokú skálán, a többi feltétel értékelése hasonló, 2,6 pont körüli átlagokkal. Mindenképpen érdekes megnézni ebben az esetben azt, hogy találhatunk-e különbségeket az elitcsoportok között a feltételek megítélésében (7. táblázat). 
Csizmadia Zoltán - Páthy Ádám : Győri elit és a városfejlödés - a gazdasági és

társadalmi folyamatok megítélése. - Tér és Társadalom 24:(2) pp. 63-91. (2010)

80 Csizmadia Zoltán - Páthy Ádám

TÉT XXIV. évf. 2010 @ 2

7. TÁBLÁZAT

Az innováció feltételeinek megítélése a különbözö elitcsoportok körében

(The Judgement of the Conditions of Innovation in the Different Elite-groups)

\begin{tabular}{lcccc}
\hline \multicolumn{1}{c}{ Elit-csoportok } & $\begin{array}{c}K+F \\
\text { infra- } \\
\text { struktüra }\end{array}$ & $\begin{array}{c}\text { Humán } \\
\text { háttér }\end{array}$ & $\begin{array}{c}\text { Pénzügyi } \\
\text { erö- } \\
\text { források }\end{array}$ & $\begin{array}{c}\text { Vállalko- } \\
\text { zások hoz- } \\
\text { záállása }\end{array}$ \\
\hline ANOVA & sig: 0,375 & sig: 0,121 & sig: 0,001 & Sig: 0,032 \\
Értelmiségiek & 2,43 & 2,72 & 2,41 & 2,42 \\
Bankok, cégvezetők & 2,72 & 3,19 & 3,00 & 2,72 \\
Oktatás & 2,40 & 2,94 & 2,06 & 2,88 \\
Egyéb intézmények & 2,33 & 3,33 & 2,67 & 2,33 \\
Önkormányzat & 2,80 & 2,80 & 2,40 & 2,80 \\
Kulturális intézmények, & 2,40 & 2,90 & 2,50 & 2,40 \\
múvészek & 2,87 & 2,75 & 2,63 & 3,12 \\
Képviselök & 2,75 & 3,00 & 2,50 & 2,00 \\
Érdekképviseletek & 2,56 & 2,98 & 2,56 & 2,61 \\
Összesen & & & & \\
\hline
\end{tabular}

Forrás: Kérdőívek (2008).

Az innovativitást nem csak az alapfeltételek rendelkezésre állása, hanem a megfelelő szereplők, intézmények is nagyban meghatározzák. A felmérés során megpróbáltunk képet kapni arról, hogy a megkérdezettek mely szereplőket tartják meghatározónak a város fejlődése szempontjából. Nemcsak az innovációt vizsgáltuk, hanem emellett kíváncsiak voltunk más területek (gazdaságfejlesztés, oktatás, környezetvédelem) kulcsszereplöinek megítélésére is. A megkérdezettek mind a négy kategóriában három-három szereplöt jelölhettek meg. A 8. táblázat mutatja be azokat a szervezeteket, intézményeket, amelyek a legfontosabb szereppel bírnak a vizsgált területeken.

A 8. táblázat jól mutatja, hogy melyek az igazán fontos, mindenhol jelen lévő szereplők, és melyek azok, amelyek általában funkciójuknál fogva specifikusak, a gazdasági élet egy-egy területén vannak jelen. Három olyan szervezetet találunk, amelyek mindenhol jelen vannak, ezek az Audi, a Széchenyi István Egyetem és az önkormányzat, rajtuk kívül az Ipari Park, a Kamara, a Rába, a Graboplast és az MTA RKK NYUTI jelenik meg egynél több dimenzióban. Ha nemcsak a jelenlétet, hanem a konkrét említéseket tekintjük, akkor a gazdaságfejlesztésben egyértelmúen megmutatkozik az Audi domináns szerepe; 157 megkérdezett adott érvényes választ a kérdésre, közülük csak ketten nem jelölték meg az autógyártó céget. A következő szereplö a sorban az Ipari Park mindössze 49 említéssel. Az innováció esetében kissé árnyaltabb a kép, bár itt is az Audi kapta a legtöbb jelölést, de ebben az esetben viszonylag közel van hozzá a Széchenyi István Egyetem (102, illetve 78 említés). Az oktatás tekintetében az egyetem hasonlóan teljesít, mint az Audi a gazdaságfejlesztésnél, emellett a válaszadók több mint fele megemlíti valamelyik közoktatási intézményt, egyharmaduk pedig a Nyugat-Magyarországi Egyetemet. A környezetvédelemnél az önkormányzat, illetve a hozzátartozó cégek, valamint különböző civil szervezetek kapták a legtöbb említést. 


\section{TÁBLÁZAT}

A különböző helyi és térségi intézmények, szervezetek szerepe

(The Role of the Various Local and Regional Institutions and Organizations)

\begin{tabular}{|c|c|c|c|c|}
\hline Intézmények, szervezetek & $\begin{array}{c}\text { Gazda- } \\
\text { ságfejlesz- } \\
\text { tés }\end{array}$ & Innováció & Oktatás & $\begin{array}{l}\text { Környezet- } \\
\text { védelem }\end{array}$ \\
\hline Audi & +++ & +++ & ++ & + \\
\hline Rába & ++ & + & & \\
\hline Graboplast & + & + & & \\
\hline Ipari Park & +++ & ++ & + & \\
\hline Integrál-H & + & & & \\
\hline Önkormányzat & ++ & ++ & + & +++ \\
\hline Széchenyi István Egyetem & ++ & +++ & +++ & ++ \\
\hline Kereskedelmi és Iparkamara & ++ & ++ & + & \\
\hline Innonet & & ++ & & \\
\hline RIÜ & & + & & \\
\hline MTA RKK NYUTI & & + & + & \\
\hline közoktatási intézmények & & & t++ & \\
\hline Nyugat-Magyarországi & & & t++ & \\
\hline Egyetem & & & & \\
\hline Munkaügyi Központ & & & + & \\
\hline Megyei Kórház & & & + & \\
\hline Komszol & & & & ++ \\
\hline Reflex & & & & +++ \\
\hline Pannon-Víz & & & & + \\
\hline civil szervezetek & & & & +++ \\
\hline
\end{tabular}

Jelmagyarázat: +++ kulcsszereplő (több mint 40 említés), ++ fontos szereplő (20-40 említés), + kiegészítő szereplő (1-19 említés)

Forrás: Kérdöívek (2008).

\section{Humán és szimbolikus tényezők}

Egy nagyváros helyzete és helyzetének megítélése, fejlődési pályaíve és jövője nemcsak az olyan 'kemény', megfogható, mérhető vagy könnyen körülírható tényezők függvénye, mint városhálózati pozíció, versenyhelyzet, gazdasági struktúra, közlekedés stb. Emellett számos humán paraméter is szerepet játszik, amelyek képlékenyebbek, szubjektívebbek és általában csak közvetetten kapcsolhatók össze a mérhetô, látható teljesítményekkel, lokális nagyvárosi inputokkal. Ebben a részben három szempontból vizsgáljuk meg ezeket a puha tényezőket. Először arra keressük a választ, hogy milyen a személyisége Győrnek. Emberi tulajdonságok segítségével rajzolunk egy viszonylag pontos portrét. Majd azt keressük, hogy mennyire elégedettek a város meghatározó, prominens társadalmi rétegének képviselői a helyi adottságokkal és szolgálttatásokkal. Végül Győr jelenének és jövőjének szimbolikájára vonatkozó eredményeinket mutatjuk be. 


\section{A helyi társadalom személyisége}

Egy új, kísérleti jellegú kérdéssorozat formájában megpróbáltuk felmérni a város tipikus személyiségjegyeit. Pozitív és negatív emberi tulajdonságokkal kellett jellemeznie a megkérdezetteknek Győrt. Nem egy konkrét aspektusát emeltük ki a nagyvárosi létnek - mint például milyen emberekre alkalmazható jelzőkkel írható le a helyi gazdasági rendszer, vagy éppen a politikai mezö -, hanem úgy általában a város egészét kellett minősíteni, a város, mint élö, lüktető vagy éppen pangó társadalmi entitást, egyfajta 'kollektív élölényt'. Természetesen ezt a feladatot megfelelő tulajdonságok előzetes leválogatása alapján lehetett csak a válaszadókra testálni. Harminc jellemvonást válogattunk össze, amelyböl tíz volt inkább negatív és húsz pozitív jellegü. A kérdés úgy hangzott, hogy melyek azok, amelyek inkább jellemzőek, és melyek azok, amelyek inkább nem jellemzöek a városra. Az eredmények értékelésekor természetesen azt nem tudjuk megmondani, hogy mire alapozva minősítették az egyes tulajdonságokat az emberek.

\section{5. ÁBRA}

A város negatív és pozitiv tulajdonságainak ,rangsora"

(The Order of Rank of the Town's Positive and Negative Attributes)

A negativ tulajdonságok gyakorisági "rangsora"

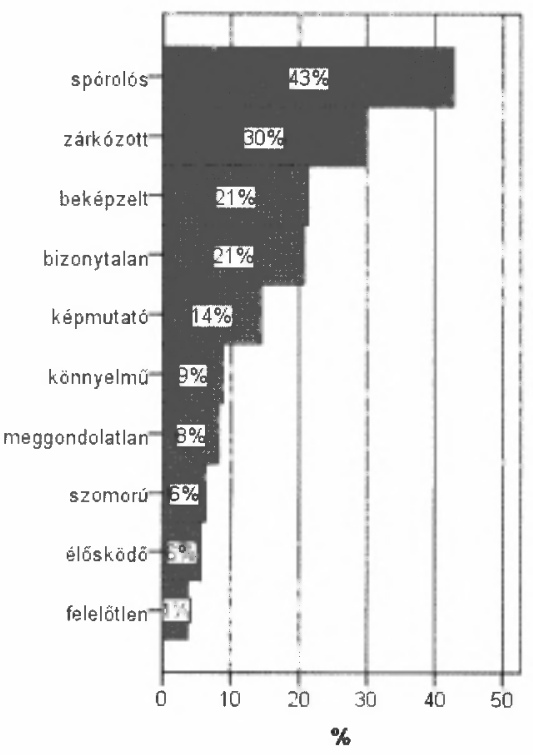

A pozitív tulajdonságok gyakorisági "rangsora"

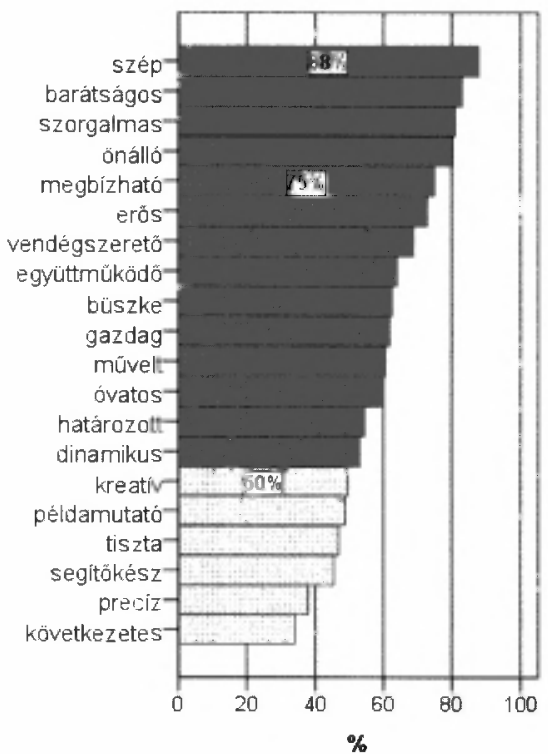

Forrás: Kérdőívek (2008).

Kezdjük a legfontosabb kérdéssel. Melyek azok a 'személyiségjegyek' amelyek a többség értékítélete alapján a leginkább jellemzőek Győrre? Ezt az egyes tulajdonságok mellé „leadott igenlő szavazatok” gyakoriságából lehet a legegyszerübben ki- 
következtetni. Az elöfordulási arányok alapján két negatív és négy pozitív tulajdonság lehet a város személyiségprofiljának domináns összetevője (5. ábra). Röviden így jellemezhetjük: spórolós és zárkózott, de ennek ellenére mégis csak egy szép, barátságos, önálló és szorgalmas társadalmi entitás. Folytatva a kérdést a negatívumokkal, a megkérdezettek egyötöde emellett még a beképzelt és a bizonytalan jelzőket is megjelölte. A pozitív lista középmezőnyének belső rangsorában a megbízhatóság, az erő és a büszkeség dominál, majd az együttmüködő készség, a gazdagság, a mủveltség és dinamizmus. Ezeket a válaszadók 60-70\%-a tartotta helyénvaló, Győrre illő jellemzőnek. Sokat elárul a helyi társadalomról és a lokális intézményi struktúrákról a legkevésbé preferált pozitív alaphangú személyiségjegyek halmaza a lista alján. A legtöbben a következetességet, a precizitást, a segítőkészséget hiányolják. Kritikai alapon közelítve a megismert személyiség profilhoz, jól kirajzolódnak azok a társadalmi jellemzők, amelyek a fejlődés és az egészséges, vagy optimális miliő szempontjából nem elhanyagolhatóak: a társadalom nyitottsága, a reális léptékủ költekezés (beruházás), a következetesség (pl. fejlesztéspolitika, igazgatás, munkavégzés, világnézet?), a precizitás és kreativitás, amelyekből jelenleg még talán kissé deficites a helyi társadalom az elit véleménye szerint.

A személyiségprofil alapvonalainak felvázolása után vizsgáljuk meg a városra ragasztott címkék számszerüsíthetô jellegzetességeit is. Azt, hogy egyáltalán az általunk felsorolt listából összesen hány tulajdonságot tartottak helytállonak a város prominens személyiségei? Milyen a negatív és a pozitív tulajdonságok számának egymáshoz viszonyított aránya? Kik voltak azok, akik kritikusabban álltak a dologhoz, és kidomborították Győr 'sötétebb oldalát' is a válaszaikban? A 171 válaszadó egyharmada egyetlen negatív tulajdonságot sem adott meg. A pozitív oldalon a nemlegesen válaszolók aránya összesen csak $2 \%$. A városhoz rendelt tulajdonságok számának átlagértékei is gyökeresen különböznek a kedvező és kedvezötlen aspektusok tekintetében. Átlagosan csak egy-egy negatív elemet azonosítottak be, míg az előnyös jelzők felsorakoztatásakor az átlag legalább 12 tulajdonságot megnevezett.

Ha összepárosítjuk a két kérdéssort, akkor viszonylagos pontossággal az is megadható, hogy mennyire voltak következetesek a helyi társadalom meghatározó, befolyásos rétegébe sorolt személyek, mint kérdőívalanyok, illetve az is, hogy milyen struktúrába rendezhető ez a réteg az értékelésük egy negatív-pozitív pólusú tengelyen szerveződö logikája alapján. Az alapvető kérdés az, hogy akik több negatív tulajdonságot is megadtak, vajon csak komplexen gondolkodtak (és hasonlóan sok kedvező jellemzőt is megjelöltek), vagy alapvetően elégedetlenek, és inkább csak a problémákra hívták fel a figyelmet (következetesen jelöltek a listából)? Amennyiben így áll a dolog, akkor az sem mellékes, hogy mekkora ezen személyeknek a köre a társadalom prominens csoportjában. A pozitív jellemzők esetén a három csoport nagyjából egyforma méretü. A negatív tulajdonságoknál kevesebben vannak azok, akik viszonylag sok tulajdonságot rendeltek hozzá a város személyiségprofilját leíró válaszukhoz (21\%). Ez összesen harminchat embert jelent a mintában. Ez a csoport jól láthatóan nem bánt bőkezủen a pozitív jelzőkkel: csak 14\%-uk 
nevezett meg az átlagosnál több pozitív jelzőt is. Ök a komplexen gondolkodók, a teljes válaszadói kör 3\%-át kitéve. Többségük viszont inkább csak átlagos, de főként az átlagnál alacsonyabb számú kedvező tulajdonságot rendelt hozzá a városhoz. Őket nevezhetjük az elégedetleneknek vagy kritikusoknak. A válaszadók 18\%-a ide sorolható. Az egyértelmúen optimistákat, az elsődlegesen pozitív személyiségprofilt megrajzolókat a 9. táblázat jobb felső celláinak értékei alapján tudjuk beazonosítani. A válaszadók durván egyharmada sorolható ide az átlagosnál több pozitív jelző és hiányzó vagy csak minimális kedvezőtlen tulajdonság kombinálása révén.

\section{TÁBLÁZAT}

Véleménycsoportok a negativ és a pozitív jelzök használatának következetessége alapján

(Opinion Groups According to the Consistent Usage of Negative and Positive Attributes)

\begin{tabular}{|c|c|c|c|c|c|c|}
\hline \multirow{2}{*}{$\begin{array}{l}\text { Negatív tulaj- } \\
\text { donságok } \\
\text { számának } \\
\text { megitélése }\end{array}$} & & & \multicolumn{3}{|c|}{$\begin{array}{l}\text { Pozitív tulajdonságok számának } \\
\text { megitélése }\end{array}$} & \multirow[b]{2}{*}{$\begin{array}{l}\text { Teljes } \\
\text { minta }\end{array}$} \\
\hline & & & $\begin{array}{c}\text { Átlag } \\
\text { alatti } \\
(0-10)\end{array}$ & $\begin{array}{l}\text { Átlagos } \\
(11-13)\end{array}$ & $\begin{array}{l}\text { Átlag feletti } \\
\quad(14-20)\end{array}$ & \\
\hline $\begin{array}{l}\text { NINCS NEGATÍV } \\
\text { tulajdonsága a } \\
\text { városnak }\end{array}$ & $\begin{array}{l}\mathrm{N} \\
\text { Sor \% } \\
\text { Teljes } \\
\text { belïli \% }\end{array}$ & mintán & $\begin{array}{l}16 \\
30,2 \% \\
9,4 \%\end{array}$ & $\begin{array}{l}16 \\
30,2 \% \\
9,4 \%\end{array}$ & $\begin{array}{l}21 \\
39,6 \% \\
12,3 \%\end{array}$ & $\begin{array}{l}53 \\
100,0 \% \\
31,0 \%\end{array}$ \\
\hline $\begin{array}{l}\text { CSAK EGY-KÉT } \\
\text { NEGATÍv tulaj- } \\
\text { donsága van a } \\
\text { városnak }\end{array}$ & $\begin{array}{l}\mathrm{N} \\
\text { Sor \% } \\
\text { Teljes } \\
\text { belüli \% }\end{array}$ & mintán & $\begin{array}{l}19 \\
23,2 \% \\
11,1 \%\end{array}$ & $\begin{array}{l}29 \\
35,4 \% \\
17,0 \%\end{array}$ & $\begin{array}{l}34 \\
41,5 \% \\
19,9 \%\end{array}$ & $\begin{array}{l}82 \\
100,0 \% \\
48,0 \%\end{array}$ \\
\hline $\begin{array}{l}\text { TÖBB NEGATÍV } \\
\text { tulajdonsága is } \\
\text { van a városnak }\end{array}$ & $\begin{array}{l}\mathrm{N} \\
\text { Sor \% } \\
\text { Teljes } \\
\text { belüli \% }\end{array}$ & mintán & $\begin{array}{l}21 \\
58,3 \% \\
12,3 \%\end{array}$ & $\begin{array}{l}10 \\
27,8 \% \\
5,8 \%\end{array}$ & $\begin{array}{l}5 \\
13,9 \% \\
2,9 \%\end{array}$ & $\begin{array}{l}36 \\
100,0 \% \\
21,1 \%\end{array}$ \\
\hline Teljes minta & $\begin{array}{l}\mathrm{N} \\
\% \\
\text { Teljes } \\
\text { belüli } \%\end{array}$ & mintán & $\begin{array}{l}56 \\
32,7 \% \\
32,7 \%\end{array}$ & $\begin{array}{l}55 \\
32,2 \% \\
32,2 \%\end{array}$ & $\begin{array}{l}60 \\
35,1 \% \\
35,1 \%\end{array}$ & $\begin{array}{l}171 \\
100,0 \% \\
100,0 \%\end{array}$ \\
\hline
\end{tabular}

Pearson Khi-négyzet próba - sig: 0,003

Forrás: Kérdőívek (2008).

Ezek alapján jogosan merül fel a kérdés, kik tartoznak ebbe a két szélső csoportba? Van valamilyen sajátos megkülönböztetö jegyük a helyi eliten belül? A társadalmidemográfiai faktorok legtöbbje nem áll szignifikáns kapcsolatban ezzel az attitüddel. Néhány háttérváltózó azért segít leírni a kritikusabb beállítódású személyek körét. 
Egyrészt felülreprezentáltak a tősgyökeresek ( $\mathrm{kb}$. kétharmaduk), vélhetően erősebb lokális identitással és ebböl fakadó érzékenységgel, amely leképeződik az általuk megrajzolt személyiségprofilban is. Másrészt szignifikáns összefüggés van a kritikai hangnem és az életével való általános elégedettség között. Az emberek elégedettségét hat konkrét kérdésen keresztül mértük. Az életszínvonalat, a munkát, a jövedelmet, a lakást, a lakókörnyezetet és az egészségi állapotot kellett értékelni egy tízfokozatú skálán. Ebből alakítottuk ki az egységes elégedettségi indexet mind a hat tényezó együttes figyelembevételével. A kritikusabb csoportban alacsonyabb az általános elégedettségi index is. Ebből arra következtethetünk, hogy ez a kritikusabb hangvétel talán csak a lenyomata, következménye a privát életben megfigyelhető elégedetlenségnek, vagy a válaszadók alapvető mentalitásából fakad mindkét kérdéssornál a negatív beállitódás. Az alapvetően kedvező tulajdonságokat megnevezők esetében szintén van néhány társadalmi sajátosság. A negyven év alattiak körében kétszer akkora az arányuk, mint a 60 év felettieknél, tehát az életkor szerepet játszhat a dologban. A tősgyökeres győriek körében viszont jóval kisebb az ilyen beállítottságú személyek aránya (csak 14\% szemben a 20\%-os mintaátlaggal). Az iskolai végzettség is szerepet játszik: magasabb a föiskolai végzettségüek aránya szemben az egyetemi vagy doktori fokozattal rendelkezőkkel.

\section{Objektív elégedettség, fejlesztési prioritások}

A város személyiségjegyeinek vizsgálatakor felszínre került a helyi gazdasági és társadalmi élettel összefüggő elégedettség is a negatív és pozitív jelzők használata alapján. Ezt objektívebb formában külön mértük a kérdöívben. Huszonkét városi adottságot és szolgáltatást soroltunk fel, melyeket egy négyfokozatú skálán kellett minősíteni (1: nagyon elégedetlen; 4: nagyon elégedett). Emellett meg kellett jelölni azt a három területet, amelyet legelőször fejlesztene a válaszadó. A válaszok alapján megadható a helyi társadalom prominens csoportjának objektívebb elégedettségi indexe, az egyes adottságok hierarchiája és a leginkább fejlesztendö területek listája. Összegezve a 22 területen adott pontszámokat megadható a válaszadók átlagos elégedettségi indexe. $\mathrm{Az}$ index átlaga és mediánja is 2,7, ami arra utal, hogy inkább elégedett a többség a város különböző adottságaival. A nagyon elégedetlenek száma alacsony, a megkérdezettek 2-3\%-a sorolható csak ebbe a csoportba. Az inkább elégedetlen kategóriába az összes válaszadó 20\%-a tartozik. Durván 60\%-uk minösíthetó átlagosan inkább elégedettnek, és további $12 \%$-uk nagyon elégedettnek abban az esetben, ha összesítetten kezeljük a 22 mért városi paramétert.

A legnagyobb problémák egyértelmüen a közlekedéssel vannak Győrben: az útminőség és a parkolás esetén az elégedettségi index értéke messze alacsonyabb a többi dimenzióban megfigyelhetô átlagoknál. E két területtel a többség nagyon elégedetlen volt. Ezen túlmenően a lakosság közérzetével összefüggỏ olyan faktorok kaptak még kedvezötlenebb minősítést, mint a környezeti kérdések, a köztisztaság és a helyi társadalom közösségi élete. A legnagyobb fokú elégedettség a globalizáció és a hazánkban is formálódó poszt-indusztriális (vagy tudás) társadalom két alappillére 
esetében figyelhető meg. A fogyasztói társadalom kiszolgáló intézményrendszere és az ehhez kapcsolódó pénzügyi szolgáltatások, illetve az oktatás-képzés teljes intézményi hierarchiája (az óvodától az egyetemig) nagyon kedvező minősítést kapott az elégedettségi rangsorban. Ezekben az alapvető szolgáltatási szektorokban, úgy tủnik, jól teljesít a város intézményrendszere a helyi prominens csoport szerint. A kettô közötti inkább elégedett zóna a legnagyobb elemszámú a felsorolt paraméterek száma tekintetében. Itt is van egy belső struktúra, ahol a munkalehetőségek, a kulturális és az egészségügyi szolgáltatások vannak az élen, és a rekreációs funkciók (parkok, játszóterek, sportolási lehetőségek) az alsó szegmensben (10. táblázat).

10. TÁBLÁZAT

22 darab városi adottság és szolgáltatás értékelése

(The Evaluation of 22 Facilities and Services)

\begin{tabular}{lcc}
\hline \multicolumn{1}{c}{ Adottságok } & Átlag & Szórás \\
\hline vásárlási lehetöségek & 3,40 &, 667 \\
pénzügyi szolgáltatások & 3,38 &, 654 \\
általános iskola & 3,20 &, 612 \\
éttermek & 3,17 &, 678 \\
felsőoktatás & 3,16 &, 686 \\
óvoda & 3,08 &, 640 \\
\hline munkalehetöség & 2,99 &, 663 \\
bölcsőde & 2,82 &, 744 \\
kulturális élet & 2,75 &, 802 \\
orvosi ellátás & 2,74 &, 678 \\
közbiztonság & 2,72 &, 654 \\
szórakozási lehetőségek & 2,70 &, 749 \\
munkaerőkínálat & 2,67 &, 750 \\
szakképzés & 2,65 &, 839 \\
sportolási lehetőségek & 2,65 &, 731 \\
játszóterek & 2,61 &, 536 \\
parkosítottság & 2,58 &, 696 \\
\hline köztisztaság & 2,41 &, 669 \\
környezetvédelem & 2,29 &, 604 \\
helyi közösségi élet & 2,22 &, 669 \\
parkolási lehetöségek & 1,90 &, 729 \\
közutak minőśsége & 1,68 &, 676 \\
\hline Foras: Kédón
\end{tabular}

Forrás: Kérdöívek (2008).

Mi a teendő? Hol kellene kezdeni? Mit kellene először fejleszteni? A válaszadók három dolgot nevezhettek meg, amelyek alapján megadható egy idözités alapján rendszerezett intézkedési, beavatkozási lista (6. ábra). A többség a közúthálózat javítását, fejlesztését szorgalmazná első helyen. Az első említések 43\%-a erre 
vonatkozott. Ezzel párhuzamosan a parkolási nehézségeket is meg kellene oldani (26\%), és a környezetvédelem érdekében kellene többet tennie a városnak. A második helyen megnevezett fejlesztési területek listája tartalmilag már sokkal összetettebb. Két adottság itt is dominál, és további három fejlesztési irány emelkedik ki a sorból. Új elemként a szakképzés fejlesztését a válaszadók közel 20\%-a emelte ki. Emellett a közbiztonság, orvosi ellátás és a környezetvédelem kapott még sok szavazatot második prioritásként a válaszadók preferenciarendszerében. A harmadik említések között 10-15\%-os súllyal öt paraméter emelkedik ki: kulturális élet, munkaerőpiac, felsőoktatás, egészségügy és a helyi közösségi élet.

\section{6. ÁBRA}

A fejlesztendö terïlletek prioritásrendszere

(The Priority System of the Most Required Developments)

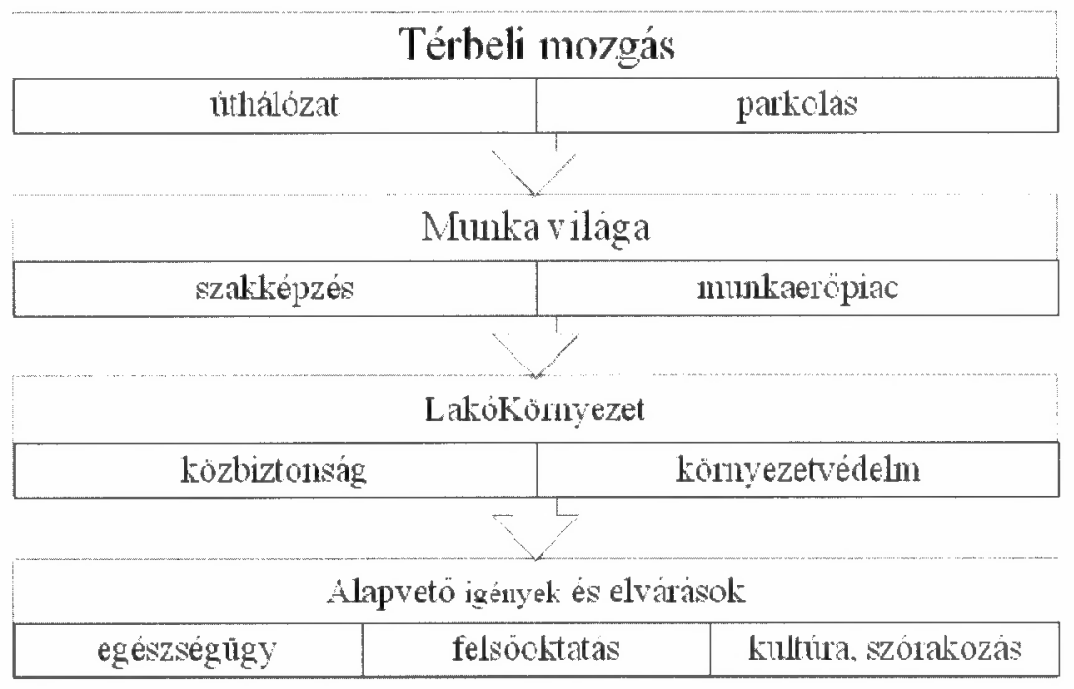

Forrás: Kérdőívek (2008).

\section{A város és környéke szimbolikája}

$\mathrm{Az}$ alapkérdésünk az volt, hogy mi szimbolizálja a legjobban a várost a helyi társadalom felső rétegének prominens személyiségei szerint. A várost megszemélyesítő attribútumok mellett ez a kérdés is a 'materiális' természetü, tényadatokra és kézzelfogható eredményekre alapozott ismereteink kiegyensúlyozását szolgálja. Tisztában kell lenni a városkép és városmarketing szempontjából a szlogenek és szimbólumok jelentőségével. Az eredmények az eddigi ilyen jellegủ kampányok lenyomatai is lesznek egyben, hiszen a véleményalkotás a már meglévő keretrendszerben történik meg. Így a két kérdés, miszerint mi szimbolizálja Győr jelenét és jövőjét, megerösitó, legitimáló és talán ötletadó is lehet egyszerre. 
Meglepő módon a nyitott kérdések ellenére is roppant leegyszerüsített a szimbólumlista. Lényegében a válaszadók 75\%-a csupán három szimbólum valamelyikét említette meg, noha nem elöre definiált lehetöségekre kellett válaszolniuk. Ezen túl, a minta maradék egynegyede még 10-15 olyan lehetséges szimbolikus elemet nevezett meg, amelyek más aspektusokat is kiemelnek, de itt az alacsony említési ráta miatt nem beszélhetünk kollektív véleményről. Megdöbbentö, de a helyi elit közel 40\%-a a "Városházát" említette meg egy teljesen nyitott kérdésfeltevés során, ahol semmilyen formában sem, befolyásoltuk a válaszadást prekoncepcióinkkal. A második legnagyobb arányú válaszcsoport a „folyók” elnevezést kapta, amelybe olyan megnevezések kerültek, mint folyók városa, Duna, Rába, hidak. Végül kiemelkedik a válaszstruktúrából az AUDI Hungária Motor Kft. melyre a minta 13\%-a 'szavazott' Győr lényegét legjobban kifejező szimbólumként (7. ábra). Jóval kisebb válaszadási rátával (5-6 említés) a sort az ,ipar”, a „Puispökvár”, az „óváros”, a „balett”, a „barokk”, illetve az „egyetem” követi.

\section{7. ÁBRA}

A város elsödleges szimbólumai

(The Primary Symbols of the Town)
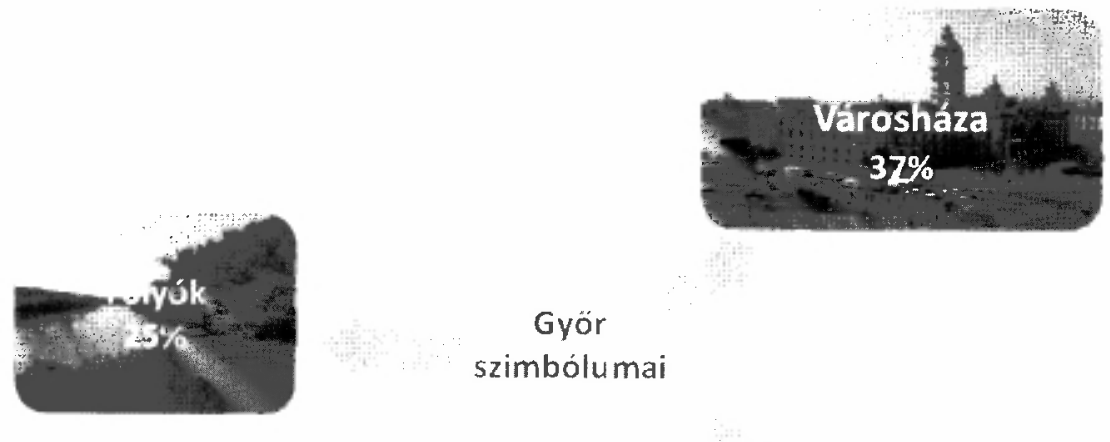

Magyarázat: Az ábrán a három legtöbbet említett szimbólum van jelölve.

Forrás: Kérdőívek (2008) alapján; www.audi.hu; saját fotó.

Második lépésben arra kellett válaszolni, hogy mi szimbolizálná Györ jövöjét a legszemléletesebben. Nagyjából azonos motívumok térnek vissza közel hasonló megoszlásban, de a válaszok sokszínübbek, precízebbek ebben az esetben. Négy szimbólumrendszer körvonalai rajzolódnak ki a válaszokban, amelyeket fontosságuk szerint ismertetünk. A legtöbb válasz ebben az esetben is a Városházára, mint épületre alapozott szimbolizmust erösíti meg, illetve az egyéb fontos és értékes helyi épített örökséget is ide lehet sorolni (pl. Püspökvár, Széchenyi tér, Káptalandomb). A másik fơirány természetesen a folyókra alapozott szimbolizmus: folyók, 
vizek városa, vizek találkozása, híd, találkozási pont, hajó, kikötő, három folyó, aktív folyó kapcsolat, egy szíven átfolyó folyó. A harmadik dimenziót az autóipar és az erre épülő fejlesztések jelentik: Audi, egyetem, autógyártás, csúcstechnológia, innováció, tudásközpont. Végül a negyedik nagyobb csoportot a kultúra és turizmus szimbólumainak gyảjtötégelyeként lehetne leírni: balett, kulturális rendezvények, tánc, turizmus. Jól látható, hogy a rendszerváltás óta eltelt két évtized image-építési és arculattervezési lépései visszaköszönnek a válaszokban, illetve kiegészült a lista olyan új elemekkel, amelyek világos reakciók a gazdasági fejlödés hátterében álló szereplökre és folyamatokra (autóipar), illetve az új társadalmi struktúra domináns formálóira (tudásteremtés, innováció).

\section{Város jövője}

Ha röviden össze kellene foglalnunk azt, hogy miként látja a város jövöjét a győri elit, akkor elsősorban néhány olyan kérdéskörre kell visszautalnunk, amelyek jelen tanulmányban már előkerültek a versenyképesség, illetve a versenytársak vizsgálatakor.

Általánosságban elmondható, hogy a válaszadók jelentös része az utóbbi néhány év tekintetében bizonyos megtorpanást tapasztalt Győr fejlódésében, ezzel szemben viszont elmondhatjuk, hogy a jövővel kapcsolatos megítélések sokkal pozitívabbnak tekinthetök. A 8. ábra mutatja, hogy amíg a 2000 és 2007 közötti idöszakban a válaszadók $43,5 \%$-a észlelte úgy, hogy a város versenypozíciói romlottak, addig azok aránya, akik szerint ez a visszafejlödési tendencia az elkövetkező tíz évben is tartani fog, mindössze 18,8\%; a másik oldalon az elmúlt időszakban javulást észlelők mintegy egyharmados aránya a jövővel kapcsolatos pozitív várakozások esetében $50 \%$ körülire emelkedik.

Ha a vélemények átalakulásával kapcsolatban a minta belső szerkezetét is vizsgáljuk, akkor elmondható, hogy szignifikáns és nagyon erös kapcsolat van a közelmúltra és a közeljövőre vonatkozó megítélések között. Azok közül, akik javulást tapasztaltak az utóbbi néhány évben, csak elvétve akadnak olyanok, akik változtatnának a véleményükön a jövővel kapcsolatban, van viszont egy masszívnak tekinthetó réteg, a válaszadók nagyjából egyötöde, akik negatív folyamatokat tapasztaltak a közelmúltban és a jövővel kapcsolatban is pesszimisták. Ha szignifikáns eltéréseket nem is találhatunk, elmondható, hogy a „stabil” pesszimisták közé nagyobb arányban kerültek az értelmiségiek, illetve talán meglepő módon a fiatalabb válaszadók. 


\section{8. ÁBRA}

Györ versenyképességének megítélése a 2000-2007 közötti idöszakra, illetve az elkövetkezó tiz évre vonatkoztatva

(The View of the Competitiveness of Györ in the Period of 2000-2007 and in the Next 10 Years)

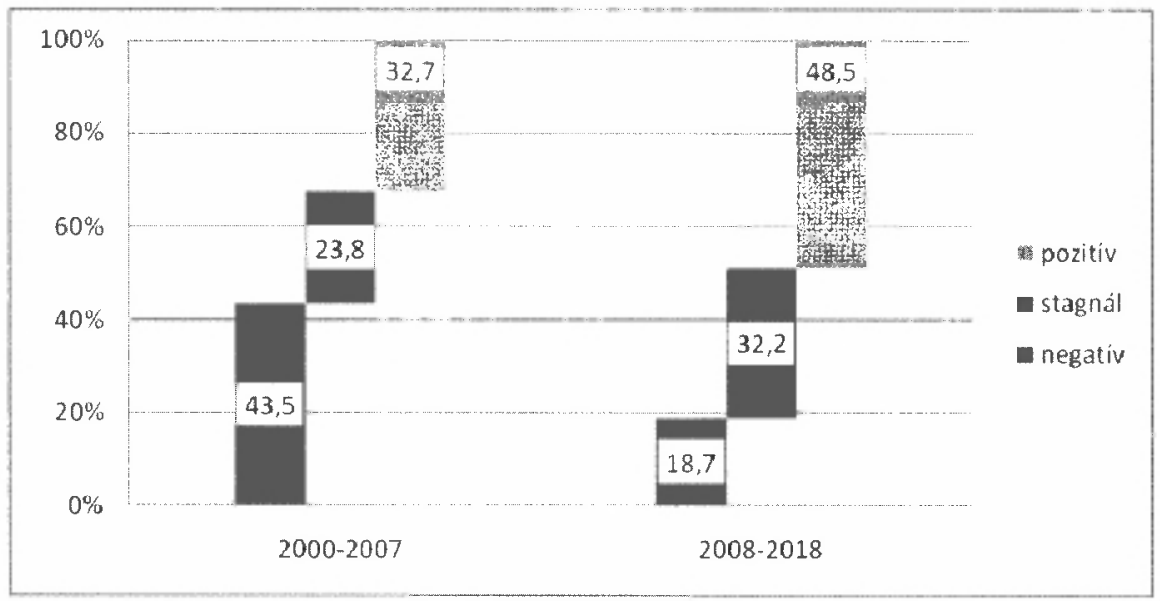

A megoszlások jellemzői a két időpont összevetésében: Pearson khí-négyzet próba - sig: 0,000; Kendall-tau-b: $-0,402$

Forrás: Kérdöivek (2008).

\section{Összefoglalás}

A felmérés során tesztelni lehetett, hogy a helyi társadalom felső rétege elérhető-e és megszólítható-e kérdőíves adatfelvétellel, amely általában ritkán alkalmazott módszer az elitkutatásokban. Az alacsony válaszadási ráta érzékelteti ennek a megoldásnak is a korlátait, de ennek ellenére is jóval gyorsabb és olcsóbb megoldással volt elérhetô több mint 170 prominens személy a hagyományos mélyinterjús megoldásokkal szemben. Tartalmi szempontból újdonságnak minősülhet az az eredmény, hogy mérhetővé és összehasonlíthatóvá tegyük a helyi társadalom személyiségjellemzőinek vagy a városi tér szimbolikájának, imázsának a faktorait, és mindezt úgy, hogy folyamatosan kapcsolatban maradhatnak (az adatbázis jelleg miatt) az ilyen képlékeny, bizonytalan hátterủ szubjektívebb tényezők a pozícionálás, a gazdasági struktúra leírás, a fejlődési trendadás vagy éppen a városi adottságok minősítésének jóval objektívebb, a reálfolyamatok tapasztalataiból jobban építkező, táplálkozó véleményrendszerei között. Célszerü lenne a jövöben összehasonlítani az eredményeket olyan új városszociológiai kutatásokkal, amelyekben más adottságú nagyvárosi (vagy éppen közép- és kisvárosi) terek felső társadalmi rétegének az attitüdjei lennének feltérképezve hasonló kérdéskörökben, hogy tisztábban lássuk az ilyen kísérleti jellegủ megoldások használhatóságát és a helyi társadalmi miliőn is túlmutató értékét. 


\title{
Jegyzet
}

${ }^{1}$ A cikk a TÁMOP-4.2.1-08/1-2008-0005 azonosító számú projekt keretében készült.

\section{Irodalom}

Csanádi G.-Csizmady A.-Kocsis J.B.-Köszeghy L.-Tomay K. (2010) Város tervezö társadalorm. Sík Kiadó, Budapest.

Enyedi Gy. (1988) A városnövekedés szakaszai. Akadémiai Kiadó, Budapest.

Izsák É. (2003) A városfejlődés természeti és társadalmi tényezói. Napvilág Kiadó, Budapest.

Mills, C.W. (1972) Az uralkodó elit. Gondolat, Budapest.

Mosca, G. (1939) Elementi di Scienza Politica. Gius, Laterza \& Figli, Barl.

Pareto, W. (1972) A kormányzó elit. - Huszár T.-Somlai P. (szerk.) A polgári szociológia története 1917-ig. 4. Tankönyvkiadó, Budapest. 278-283. o.

Rechnitzer J. (2007) Az európai regionális politika és városfejlödés. - Magyar Tudomány. 6. 692-703. o.

Szirmai V. (szerk.) (2009) A várostérségi versenyképesség társadalmi tényezöi. Dialóg Campus, PécsBudapest.

Szirmai V.-Baráth G.-Bognár J. (2003) Globalizáció és városfejlődés Budapesten. - Társadalomkutatás. 3. 249-274. o.

Takács K. (1998) Az elit szociológiai fogalmáról. - Szociológiai Szemle. 1. 139-148. o.

Veblen, Th. (1992) The Theory of the Leisure Class. Transaction Publishers, New Brunswick - New Jersey.

\section{LOCAL ELITE AND URBAN DEVELOPMENT - THE OUTLOOK OF ECONOMIC AND SOCIAL PROCESSES}

\author{
ZOLTÁN CSIZMADIA - ÁDÁM PÁTHY
}

Opinions and expectations about the economic and social development and the premises of a liveable city can be usually considered as a useful tool for measuring the satisfaction with life or the attachment to the town. It might be even more interesting if these opinions come from the local elite, a group that has the ability to form the image of the city to some extent and plays an important role in the local development and competitiveness. The aim of this paper is the complex analysis of a survey taken among the prominent actors of the political, economic and cultural life in Györ. The survey was focused on two major dimensions. The economic development and competitiveness was examined by exploring the existance of prerequisites necessary for a town to be 'European', positioning Györ in the Central-European economic and cultural space and analysing the recent and future changes in the structure of local economy. The second dimension is the sphere of human and symbolic factors. In this case we made an attempt to describe the 'personality' of Györ, gathering the opinions on the physical and social environment and the possible symbols of the city. 